\title{
Behind the Audit Report: A Descriptive Study of Discussions and Negotiations Between Auditors and Directors
}

\author{
Vivien Beattie ${ }^{a^{*}}$, Stella Fearnley ${ }^{b}$ and Richard Brandt ${ }^{b}$ \\ aUniversity of Stirling, UK \\ ${ }^{b}$ University of Portsmouth, UK
}

This paper presents direct evidence concerning the extent, nature, and outcome of interactions between the two primary parties in the auditor-client relationship - finance directors (FDs) and audit engagement partners (AEPs). A questionnaire instrument is used to elicit the frequency with which, over a three year period, an extensive set of 46 audit and audit-related issues is discussed, is negotiated, and results in a change to either the accounting numbers or disclosures. Three hundred FDs and 307 AEPs of listed UK companies are surveyed, with response rates of $51 \%$ and $80 \%$, respectively. Principal findings are that: (i) compliance issues dominate discussions, while accounting and fee issues dominate negotiations; (ii) audit committees generally reduce the level of negotiation and increase the level of discussion, suggesting that the overall degree of confrontation declines; and (iii) in the majority of cases $(57 \%)$, negotiation results in a change to the financial statements, providing evidence of the auditor's influence on the financial statements.

Keywords: audit; audit committees; audit process; conflict; discussion; interaction; negotiation; relationship.

\section{SUMMARY}

This paper represents the first stage of an investigation into the interaction that takes place between the two primary parties in the auditorclient relationship - finance directors (FDs) and audit engagement partners (AEPs). While the existence of discussion and negotiation has been anecdotally reported, no systematic evidence exists as to the extent, nature and outcome of

*Correspondence to: Department of Accounting, Finance and Law, University of Stirling, Stirling, FK9 4LA, UK. Tel. +44-1786 467306; Fax +44-1786 467308. this interaction. The theory in the literature creates an abstracted reality (a black box) that does not adequately describe what is actually happening. This paper seeks to begin to fill this void, by exploring the scope of interactions using a static, questionnaire approach. A questionnaire instrument is used to elicit the frequency with which, over a three year period, an extensive set of 46 audit and audit-related issues is discussed, is negotiated, and results in a change to either the accounting numbers or disclosures. Three hundred FDs and 307 AEPs of listed UK companies are surveyed, with response rates of $51 \%$ and $80 \%$, respectively. The 
large sample size allows us to generalise our findings to the population as a whole.

The level of interaction activity is characterised as 'high'. Four issues are discussed by more than $50 \%$ of FD respondents and 12 issues are discussed by more than $50 \%$ of AEP respondents. By comparison, two issues are negotiated by more than $20 \%$ of FD respondents and eight issues are negotiated by more than $20 \%$ of AEP respondents. Compliance issues are found to dominate discussions, while fee issues and issues representing potential earnings management instruments dominate negotiations. For many issues, AEPs perceive a significantly higher absolute level of interaction than FDs, although the two groups' rankings are highly correlated (in excess of 0.7). In aggregate, auditor/auditee interactions have a significant impact upon the content of financial reports, the mean number of reported changes to the accounting numbers (disclosures) being 1.3 (2.9) and 3.4 (6.1) for the FD and AEP groups, respectively. In the majority of cases $(57 \%)$, negotiation resulted in a change to the financial statements, providing evidence of the auditor's influence on the financial statements.

Audit committees generally reduce the level of negotiation and increase the level of discussion, suggesting that the overall degree of confrontation declines. We find no evidence of a link between the extent of interaction and either the duration of the auditor-client relationship or the level of non-audit fees in relation to audit fees paid to the incumbent auditor. These findings are interpreted as inconsistent with, respectively, long-term auditor-client relationships becoming 'stale' and with auditor independence being compromised.

The level of discussion revealed suggests that the traditional agency model of audit is an inadequate characterisation of the activities of external auditors in relation to the client company. The auditor is found to be a source of support and advice, with the final accounts generally resulting from a cooperative effort. However, in the case of significant accounting issues, and where the main parties are unable to agree, third parties (i.e., audit firm technical department, independent internal second opinion, audit committee, and [indirectly] the Financial Reporting Review Panel) are influential in the final outcome. This indicates that, at the negotiation stage, interactions involve multiple parties. Future research into the ability of auditors to withstand pressure from directors should recognise this. The implication of these findings for the impact of 're-engineered' audits on auditor independence is discussed.

The factual evidence presented here provides a useful frame of reference for the development of a line of research that seeks to open the 'black box' relating to auditor-client interaction. Further research (currently underway) that undertakes in-depth, matched interviews will allow the current findings to be contextualised and will permit the dynamics of the interaction process to be fully explored.

\section{INTRODUCTION}

A 'robust independent audit process' is fundamental to the integrity of financial reporting which is, in turn, fundamental to confidence in the capital markets (APB, 1994). In recent years, the trend towards downsizing has meant that management is increasingly seeking additional support and advice from the auditor in the areas of internal control, guidance on accounting principles, and general business advice (Beattie and Fearnley, 1998a, p.20 and pp.24-25). These developments suggest that the traditional audit model based on agency theory is likely to be partial and inadequate.

To date, most research into auditor-client interactions is either highly abstract, adopting an analytical or experimental approach (e.g., Fellingham and Newman, 1985; Fisher et al., 1996) or indirect (e.g., studies that seek to draw inferences from publicly available data). This focus is undoubtedly due to the obvious difficulties associated with gaining access to real-life settings (Dye, 1991, footnote 1). This paper adds to our knowledge by conducting an exploratory, descriptive study of the type of issue discussed during interactions between auditors and clients, the form that the interaction takes, and the outcome of the interaction in terms of the financial statements. We focus on interactions between the audit engagement partner (AEP) and the finance director (FD), since this is the primary relationship between the auditor and the client (Beattie and Fearnley, 1998a, p.23). Ultimately, it is the AEP who is responsible for evaluating the large body of audit evidence gathered throughout the course of the audit and discussing the findings with the client, with the 
principal point of contact for the AEP being the FD. ${ }^{1}$

It is to be expected that interactions will primarily concern the content of financial reports and the general conduct of the audit. The nature of these interactions can range from a simple exchange of information, through discussion, to negotiation required to resolve conflict. ${ }^{2}$ A particular and growing concern here is the auditor's ability to resist management pressure in the discussion of major issues and problems, since this relates to auditor independence (e.g., APB, 1992; and ICAS 1996 in the UK and also the creation of an Independence Standards Board in 1997 in the US). This lack of neutrality is believed to contribute to creative accounting (in particular, earnings management), whereby auditors permit aggressive reporting methods (e.g., Schuetze, 1994; Levitt, 1998). The accounting and auditing regulatory framework, in particular the flexible interpretation of accounting standards and the effectiveness of audit regulation, represents the context within which interactions occur between auditors and auditees.

The remainder of this paper is structured as follows. Section two briefly reviews the limited and diverse accounting studies concerning interactions between auditors and auditees during the audit process. Research questions are presented in section three. Section four outlines the sample selection procedures, describes the development and content of the research instrument, and summarises the questionnaire administration procedures used. Response rates, tests for bias, and response distributions are presented in the fifth section. Detailed results are presented and discussed in section six. The final section concludes.

\section{RELATED ACCOUNTING STUDIES}

The generic process of negotiation, studied across a wide range of settings, has been the subject of detailed analysis in the social sciences. The concepts used in this literature require careful definition. Negotiation is defined as 'processes of interaction between disputing parties whereby, without compulsion by a thirdparty adjudicator, they endeavour to come to an interdependent, joint decision concerning the terms of agreement on the issues between them' (Gulliver, 1979, p.79, emphasis in original).
Negotiation encompasses bargaining, which 'consists of the presentation and exchange of more or less specific proposals for the terms of agreement on particular issues' (Gulliver, 1979, p.71).

The problem faced by negotiators is that of 'being interdependent while having interests which are in contrast to those of the other party' (Mastenbroek, 1989, p.56). In addition, 'negotiating presumes a certain symmetry in the balance of power' (Mastenbroek, 1989, p.63). Power can be defined as the ability of one actor to overcome resistance in achieving a desired result' (Brass and Burkhardt, 1993). Conflict can be defined as 'the interaction of interdependent people who perceive the opposition of goals, aims, and/or values, and who see the other party as potentially interfering with the realization of these goals (aims, or values)' (quoted in Nicotera, 1993). Negotiation theory is a key area of conflict research (Kramer and Messick, 1995, p.vii).

Gulliver's (1979) analytical framework captures economic, social, and psychological aspects of the negotiation process. It has been developed from actual cases which span a wide range of social, cultural and economic contexts. Two distinct, though interconnected, processes occur simultaneously - a cyclical process and a developmental process (Gulliver, 1979). The cyclical process involves the ongoing exchange of information between the parties (perhaps incorporating information from third parties). The kind of information exchanged depends on the current phase of negotiation, and may include information about procedural rules, appeals to norms, factual information, threats, and promises. The developmental process occurs through successive iterations of this cycle, as they drive the negotiation through a number of overlapping phases. The causes of convergence and the nature of the outcome can often be explained in terms of appeals to norms and other sources of power.

Accounting studies concerning interactions between auditors and auditees have used a variety of different methods, have focused upon different interaction stages, and have investigated interactions between staff at different levels on both sides of the relationship.

The theoretical literature specifically on auditor-client interactions is rather more abstract than Gulliver's (1979) negotiation 
model. It concerns strategic interactions and contains two distinct approaches. The early decision-theoretic approach (Kinney, 1975a,b) does not address the impact of the auditor's behaviour on manager's reporting decisions. The more recent Fellingham and Newman (1985) game-theoretic approach does permit the auditor's testing strategy to influence the manager's reporting decisions. For many parameter values, a Nash equilibrium strategy, rather than a cooperative strategy, is the predicted outcome. ${ }^{3}$

These alternative models have generally been tested using experimental methods. For example, Fisher et al. (1996) test the Fellingham and Newman (1985) model, and find that the model generally fails to predict a significant proportion of observed auditor and client behaviour, with the observed behaviour involving mutual cooperation. These models are acknowledged to be 'highly stylized and abstract away from some of the important and interesting features in the extant auditing environment' (Fisher et al., 1996, p.157). Recently, Hansen and Watts (1997) report on the first empirical test of the two alternative approaches using archival accounting data, finding that the game-theoretic model better describes the auditor-manager interaction. ${ }^{4}$

A further strand of research focuses on conflict relations and is motivated directly by the implications of conflict for actual and perceived auditor independence. ${ }^{5}$ This series of studies is concerned with the theoretical identification and empirical testing of variables which may explain auditors' desire and ability to withstand pressure from directors (see, for example, Firth, 1980; Knapp, 1985 and 1987; Schleifer and Shockley, 1990; Gul, 1991; Agacer and Doupnik, 1991; Lindsay, 1992; Lord, 1992; Bartlett, 1993; Trompeter, 1994; Teoh and Lim, 1996; and Beattie et al., 1999). The methods used have generally involved either a list of factors to be assessed individually or an experimental task employing a repeated-measures, fixed effects design. In combination, these studies find auditor's incentives and power to be negatively related to the percentage of office (or firm) revenue from the client, the closeness with which audit partner compensation schemes are tied to client retention, unpaid fees, the client's financial condition, the provision of non-audit services, and the level of competition among audit firms.
Positive relationships exist with respect to the inflexibility of accounting standards, audit firm size, the existence of an audit committee, and the personal accountability of the auditor.

Limited indirect evidence regarding interactions between auditors and their client companies is provided by Hill and Ingram (1989), who interpret selection of GAAP or RAP as the outcome of discussions between the client company and their auditor, and by Chambers and Penman (1984) and Kross and Schroeder (1984) who explain the delayed release of financial reports by troubled clients in terms of the additional time required to agree their contents.

Of most direct relevance to the present study is a working paper by Gibbins et al. (1999) that seeks direct evidence about auditor-client negotiations using a questionnaire approach. ${ }^{6}$ Ninety-three experienced Canadian public accounting firm partners responded in the context of a specific negotiation example selected from their experience. Client perceptions were not surveyed. They conclude that negotiation is important, frequent and contextsensitive.

They find that agreement was reported to have been reached somewhere between both parties' original positions in $41 \%$ of cases, on the auditor's original position in $32 \%$ of cases, and on the client's original position in $4 \%$ of cases. A new solution was generated in $16 \%$ of cases. The two factors said to be of most importance to the negotiation were 'accounting and disclosure standards' and 'audit firms accounting expertise'.

Finally, Antle and Nalebuff (1991) focus on the negotiation stage of auditor/auditee interaction using mathematical modelling. They show that the expected bias of the final negotiated financial reports is always upward, despite the auditor's rational conservatism during negotiations.

\section{DEVELOPMENT OF RESEARCH QUESTIONS}

Due to the exploratory nature of this study, no formal hypotheses are developed. However, the following seven research questions (RQ) are addressed:

RQ1. What issues are discussed by FDs and AEPs and what is the incidence of these discussions? 
RQ2. What issues are negotiated by FDs and AEPs and what is the incidence of these negotiations?

RQ3. What issues are of most importance to respondents and what events are associated with these interactions?

RQ4. What is the incidence of changes to the accounting numbers or disclosures arising from the audit process?

RQ5. What are the typical patterns of interaction progression?

RQ6. What is the relationship, if any, between the frequency of discussions and negotiations and (i) the existence of an audit committee, (ii) audit tenure, and (iii) level of non-audit fees paid to auditor?

RQ7. What are the observations of the individual respondents about the interaction process and its outcomes?

\section{METHODS}

\section{Sample selection}

Two samples, one of listed company FDs and one of listed company AEPs, were selected. The sample of FDs was taken from the population of domestic officially listed companies in the UK as at 30 April 1996. A systematic sample of 300 was selected from an alphabetical listing of company names. The sample of AEPs was drawn from the top 20 audit firms (Accountancy Age, 8th June 1995). To obtain a sample size similar to that for the FDs, firms were asked to identify partners acting for listed companies, the number being in proportion to the number of partners in the firm/total number of top twenty firm partners. The cooperation of the big six firms was negotiated with the assistance of the Audit Faculty of the Institute of Chartered Accountants in England and Wales (ICAEW). Ninety-seven second tier (i.e., firms ranked 7-20) and 210 big six partners were identified.

\section{Research instrument and questionnaire administration procedures.}

The research instrument used primarily closedform questions and contained four sections. To provide a specific context within which to respond, AEPs were asked to respond with reference to one specific (but unidentified and unidentifiable) listed company client; specifically, 'the listed company for whom they act as engagement partner which generates the largest total recurring fee (including non-audit services) in their listed portfolio' (emphasis in original). This client was referred to as 'client $X^{\prime}$ throughout the questionnaire.

Section A contained general questions about the company/audit firm and the auditors/ auditee. Section B concerned areas of discussion and negotiation with the auditors/client company. The definition of negotiation included in the questionnaire was selected from a review of the definitions offered in the negotiation literature (e.g., Gulliver, 1979, pp.70-79; Kennedy et al., 1984, p.3 and p.12; and Mastenbroek, 1989, p.11). The introduction to this section reads as follows:

'The process which each year culminates in the production of financial statements which are contained in a company's annual report is described as a 'process of negotiation' between the auditor and the company. Discussion on various issues takes place and may lead to negotiation. This is a continuing process which includes issues identified and discussed prior to the commencement of the final audit and is not restricted to the yearend accounts. We define 'discussion' and 'negotiation' as follows:

discussion: matters are raised by one side or the other (or both) and are considered in speech or writing;

negotiation: is the process of reconciling conflicting views advanced in discussion, by concessions on one or both sides.'

Respondents were asked to indicate which of 46 itemised issues had 'been the subject of discussion and/or negotiation between you and your auditor/client $X$ over the last three years, and whether any of these discussions or negotiations resulted in any change to your/your client's proposed accounting numbers or disclosures'. This list of 46 issues was developed from the article by Tweedie and Whittington (1990) on recognition and measurement problems in financial reporting in the UK, updated to include emergent problems since 1990 . We identified issues concerning disclosure, compliance, and audit-related matters as other areas for discussion and negotiation. The 46 issues were listed in five groups: accounting principles and practice, disclosure, balance sheet areas not 


\section{Table 1: Listing of Issues as in the Questionnaire Instrument}

\section{Accounting principles and practice}

(1) Operating and finance leases

(2) Contingent contracts (e.g. consignment stock, sale and repurchase/leaseback, factoring, etc.) (please specify)

(3) Off-balance sheet items

(4) Regularity of fixed asset revaluations

(5) Goodwill

(6) Brands

(7) Reorganisation costs

(8) Prior year adjustments

(9) Capital issues of debt or equity convertibles (please specify)

(10) Group matters:

$$
\begin{aligned}
& \text { 1. merger or acquisition } \\
& \text { accounting } \\
& \text { 2. subsidiary undertakings } \\
& \text { 3. associated undertakings } \\
& \text { 4. fair values on acquisition } \\
& \text { 5. reorganisation costs on } \\
& \text { acquisition } \\
& \text { 6. other (please specify) }
\end{aligned}
$$

\section{Disclosure}

(15) Going concern

(16) Related party transactions

(17) Environmental liabilities/contingencies

(18) Other contingencies

(19) Post-balance sheet events

(20) Fraud and illegal acts

Other (please specify)

\section{Balance sheet areas not addressed above}

(21) Stock and work-in-progress

(22) Debtors

(23) Liabilities

(24) Investments

(25) Fixed assets

(26) Deferred tax assets/liabilities

(27) Deferred pension or other post retirement benefit assets / liabilities

Other (please specify)

\section{Compliance}

(28) Maintenance of proper accounting records

(29) Issues arising from the requirement to comply with the Companies Acts and Accounting Standards not covered above (please specify)

(30) Timing of implementation of new regulatory requirements (FRSs, Cadbury, etc.)

Statements in the annual report concerning compliance with the Cadbury Code of Best Practice:

(31) 1. disclosure of directors remuneration packages and stock options

(32) 2. existence and composition of remuneration committee

(33) 3. existence and composition of audit committee 4. other (please specify)

(34) Stock Exchange reporting requirements

(35) Information provided to, or other form of communication with, a regulator (e.g. Bank of England, Financial Reporting Review Panel, etc.) (please specify)

Other (please specify)

\section{Audit-related matters}

(36) Quality of information provided by management to auditor

Failure to meet agreed audit timetable: by company by auditor Time pressures caused by late adjustments: from company

(41) Nature and content of management letters

(42) Ability to detect fraud and other irregularities

(43) Extent of audit of internal control

(44) Unexpected audit related fees

(45) Attempts to renegotiate agreed audit fees

(46) Level of non-audit fees from incumbent auditor Other (please specify) 
addressed elsewhere, compliance, and auditrelated matters, as shown in Table 1. Six 'other (please specify)' issues were included.

We also sought to get behind the frequency data concerning what was discussed and negotiated to investigate how these interactions took place, i.e., what influenced their course. The questionnaire therefore included an open-ended question on both the process of interaction and the main factors influencing its outcome.

The remainder of the questionnaire concerned perceptions of auditor independence and is reported in Beattie et al. (1999). A draft questionnaire was pretested with the assistance of several senior business executives and audit partners and the content, ordering, and terminology was revised accordingly. Questionnaires were serially numbered to allow non-respondents to be followed up, and were accompanied by an explanatory letter which included an assurance of confidentiality of responses and a return envelope. Questionnaires to FDs, and to AEPs in second tier firms, were sent direct by the researchers, whereas those to big six AEPs were distributed internally by the firm (thus preserving the AEPs', and their client's, anonymity). All responses were returned direct to the researchers. Reminder letters were sent after 11 days and a second request (together with another questionnaire and original covering letter) was sent after a further 15 days.

\section{RESPONSE RATES AND DISTRIBUTIONS}

\section{Response rates and tests for bias}

For the FD sample of 300, 153 usable responses were received, representing a response rate of $51 \%$. For the AEP sample of 307, 244 usable responses were received, representing a response rate of $80 \%$.

To test for response bias, the size group of early and late responders (first and last 25 FD respondents and first and last 55 AEP respondents) were compared on the assumption that late responders are similar to non-responders (Oppenheim, 1966, p.34). Size groups were defined in terms of turnover (three groups) for the FD sample and client $X^{\prime}$ s audit fee level (four

Table 2: Analysis of Respondents by Audit Firm Type, Company Size and Client Industry Group

\section{Finance director (FD) sample}

Audit firm type
Big six
Another international or
national
Regional or local
Joint

Item non-response

$\begin{array}{lcrr}\text { Size group } & \begin{array}{c}\text { Sales } \\ \text { turnover } \\ (£ m)\end{array} & \text { No. } & \% \\ \text { Small } & <50 & 59 & 38.6 \\ \text { Medium } & 50-200 & 38 & 24.8 \\ \text { Large } & >200 & 54 & 35.3 \\ \text { Item non-response } & & \underline{\mathbf{2}} & \underline{153} \\ & & \underline{100.0}\end{array}$

\begin{tabular}{rr} 
No. & $\%$ \\
117 & 76.5 \\
& \\
21 & 13.7 \\
9 & 5.9 \\
4 & 2.6 \\
$\frac{1}{153}$ & $\underline{100.0}$ \\
\hline
\end{tabular}

\section{Audit partner (AEP) sample}

$\begin{array}{lrr}\text { Audit firm type } & \text { No. } & \% \\ \text { Big six } & 176 & 72.1 \\ \text { Another international or } & & \\ \quad \text { national } & 67 & 27.5 \\ \text { Regional or local } & 0 & 0.0 \\ \text { Joint } & 0 & \text { N/A } \\ \text { Item non-response } & \underline{1} & \underline{0.4} \\ & \underline{244} & \underline{100.0}\end{array}$

$\begin{array}{lrr}\text { Client industry group } & \text { No. } & \% \\ \text { Capital goods } & 37 & 15.2 \\ \text { Consumer goods } & 80 & 32.8 \\ \text { Financial } & 33 & 13.5 \\ \text { Other } & 92 & 37.7 \\ \text { Item non-response } & \underline{2} & \underline{0.8} \\ & \underline{\mathbf{2 4 4}} & \underline{100.0}\end{array}$


groups) for the AEP sample. The hypothesis that early and late responders were drawn from the same population was tested using a chi-square $\left(\chi^{2}\right)$ test and was not rejected $(\alpha=0.05)$. Although this test is limited in value (see Wallace and Mellor (1988) for a discussion), we believe that, given the high response rates obtained, response bias is not a serious threat. Table 2 provides an analysis of the respondents by audit firm type, company size, and client industry group.

The validity of questionnaires can also be affected by the suitability of individual respondents, who should be both knowledgeable and involved in the relevant practices, usually at a senior level. FD respondents, based on job title, were finance director $(56 \%)$, financial controller $(9 \%)$, director $(5 \%)$; accountant $(5 \%)$, chief accountant $(3 \%)$, and other/non stated $(22 \%)$. We therefore conclude that the risk of uninformed respondent bias in this sample is minimal.

\section{Response distributions}

The distribution of responses across each respondent type is summarised in Table 3, which shows the mean, standard deviation, and median number of issues cited for each form of interaction. As would be expected, as the interaction progresses, the mean number of issues affected declines. In all cases the median lies slightly below the mean, indicating a slight positive skew in the distributions. The standard deviations are fairly large in all cases, indicating a high degree of variation among respondents. The reported incidence of all forms of interaction and change is markedly greater for the AEP sample than for the FD sample. A large proportion of issues appear, unsurprisingly, not to go beyond the discussion stage. Despite this, we were struck by the extent of reported negotiation and change to the financial statements.

\section{RESULTS AND DISCUSSION}

\section{RQ1: What issues are discussed by FDs and AEPs and what is the incidence of these discussions?}

Discussion can be interpreted broadly either as a simple exchange of information (e.g., advice if the client's technical department does not have the scope to investigate for themselves or the accounting issue is complex or new) or as elucidation and confirmation in support of the attest function. The frequency with which each of the 46 issues relating to the production and audit of annual financial statements is discussed by the auditor and auditee was calculated. Table 4 gives the frequencies and ranks for the FD and AEP samples. For ease of reference, each of the 46 issues is given a numerical code ( 1 to 46 , see Table 1). It is clear that the level of discussion

Table 3: Summary Statistics of Responses by Respondent Type

\begin{tabular}{lcccccrr}
\hline & \multicolumn{5}{c}{ Mean } & \multicolumn{2}{c}{$\begin{array}{c}\text { Standard } \\
\text { deviation }\end{array}$} \\
\cline { 2 - 8 } \multicolumn{1}{c}{ Interaction } & $F D$ & $A E P$ & $F D$ & $A E P$ & $F D$ & MEP \\
\cline { 2 - 8 } Discussion & 14.9 & 18.4 & 7.8 & 7.9 & 14 & 17 \\
\hline Negotiation & 2.7 & 5.7 & 3.2 & 5.0 & 2 & 5 \\
\hline Change to accounting numbers & 1.3 & 3.4 & 1.9 & 3.0 & 0 & 3 \\
\hline Change to disclosures & 2.9 & 6.1 & 3.4 & 4.7 & 2 & 5 \\
\hline
\end{tabular}

Note 1: The maximum number of issues is 52 for discussion and negotiation (i.e., 46 specified issues plus 6 'other', respondent defined, issues) and 40 for changes to the financial statements (i.e., 35 specified issues which could result in change plus 5 'other', respondent defined, issues) 


\section{Table 4: Frequency of Discussion of Issues}

\begin{tabular}{|c|c|c|c|c|c|c|}
\hline \multirow[b]{2}{*}{ Issue } & \multirow{3}{*}{$e^{1}$ Issue } & \multicolumn{3}{|c|}{$\begin{array}{l}\text { \% indicating discussion } \\
\text { took place }{ }^{2}\end{array}$} & \multirow{3}{*}{$\begin{array}{l}\text { AEPs } \\
\text { rank }\end{array}$} & \multirow{3}{*}{$\begin{array}{l}\chi^{2} \text { test of } \\
\text { difference } \\
\text { between FDs } \\
\text { and } \\
\text { AEPS (prob.) }\end{array}$} \\
\hline & & & & & & \\
\hline code $e^{1}$ & & $(n=153)$ & $(n=244)$ & rank & & \\
\hline 30 & $\begin{array}{l}\text { Timing of implementation of new regulatory requirements } \\
\text { (FRSs, Cadbury, etc.) }\end{array}$ & 80.4 & 86.9 & 1 & 1 & n.s. \\
\hline 31 & $\begin{array}{l}\text { Statements in the annual report concerning compliance with } \\
\text { the Cadbury Code of Best Practice re disclosure of directors' } \\
\text { remuneration packages and stock options }\end{array}$ & 72.5 & 75.4 & 2 & 3 & n.s. \\
\hline 41 & Nature and content of management letters & 64.7 & 78.3 & 3 & 2 & $\begin{array}{l}8.471^{3} \\
(0.004)\end{array}$ \\
\hline 33 & $\begin{array}{l}\text { Statements in the annual report concerning compliance with } \\
\text { the Cadbury Code of Best Practice re existence and composition } \\
\text { of audit committee }\end{array}$ & 51.6 & 54.8 & 4 & 8 & n.s. \\
\hline 7 & Reorganisation costs & 49.0 & 52.0 & 5 & 10 & n.s. \\
\hline 26 & Deferred tax assets/liabilities & 48.4 & 55.3 & $6=$ & 7 & n.s. \\
\hline 19 & Post balance sheet events & 48.4 & 47.5 & $6=$ & $15=$ & n.s. \\
\hline 15 & Going concern & 47.7 & 43.0 & 8 & 21 & n.s. \\
\hline 32 & $\begin{array}{l}\text { Statements in the annual report concerning compliance with } \\
\text { the Cadbury Code of Best Practice re existence and composition } \\
\text { of remuneration committee }\end{array}$ & 47.1 & 49.6 & 9 & 12 & n.s. \\
\hline 21 & Stock and work-in-progress & 46.4 & 47.5 & 10 & $15=$ & n.s. \\
\hline 1 & Operating and finance leases & 44.4 & 50.8 & 11 & 11 & n.s. \\
\hline 10 & Group matters: merger or acquisition accounting & 45.1 & 50.0 & 12 & 12 & n.s. \\
\hline 5 & Goodwill & 43.8 & 61.1 & $13=$ & 4 & $\begin{array}{l}10.261^{3} \\
(0.001)\end{array}$ \\
\hline 13 & Group matters: fair values on acquisition & 43.8 & 52.9 & $13=$ & 9 & n.s. \\
\hline 4 & Regularity of fixed asset revaluations & 43.1 & 45.1 & 15 & 19 & n.s. \\
\hline 43 & Extent of audit of internal control & 42.5 & 59.0 & 16 & 5 & $\begin{array}{c}10.213^{3} \\
0.001\end{array}$ \\
\hline 34 & Stock Exchange reporting requirements & 40.5 & 57.4 & 17 & 6 & $\begin{array}{l}9.648^{3} \\
(0.002)\end{array}$ \\
\hline 12 & Group matters: associated undertakings & 37.9 & 37.7 & 18 & $26=$ & n.s. \\
\hline 25 & Fixed assets & 36.6 & 40.6 & 19 & 23 & n.s. \\
\hline 11 & Group matters: subsidiary undertakings & 35.3 & 41.8 & 20 & 22 & n.s. \\
\hline 3 & Off-balance sheet items & 34.6 & 48.8 & $21=$ & 14 & $\begin{array}{l}7.009^{3} \\
(0.008)\end{array}$ \\
\hline 27 & $\begin{array}{l}\text { Deferred pension or other post retirement benefit assets/ } \\
\text { liabilities }\end{array}$ & 34.6 & 45.9 & $21=$ & $17=$ & n.s. \\
\hline 24 & Investments & 31.4 & 28.7 & 23 & $32=$ & n.s. \\
\hline 14 & Group matters: reorganisation costs on acquisition & 30.1 & 44.3 & 24 & 20 & $\begin{array}{l}7.388^{3} \\
(0.007)\end{array}$ \\
\hline 22 & Debtors & 28.8 & 36.1 & 25 & 28 & n.s. \\
\hline 23 & Liabilities & 28.1 & 37.7 & $26=$ & $26=$ & $\begin{array}{l}3.977^{3} \\
(0.046)\end{array}$ \\
\hline 8 & Prior year adjustments & 28.1 & 23.0 & $26=$ & 38 & n.s. \\
\hline 18 & Contingencies other than environmental & 26.1 & 34.4 & 28 & 29 & n.s. \\
\hline
\end{tabular}


Table 4: continued

\begin{tabular}{|c|c|c|c|c|c|c|}
\hline \multirow[b]{2}{*}{ Issue } & \multirow{3}{*}{${ }^{e}$ Issue } & \multicolumn{3}{|c|}{$\begin{array}{l}\% \text { indicating discussion } \\
\text { took place }\end{array}$} & \multirow{3}{*}{$\begin{array}{l}A E P s \\
\text { rank }\end{array}$} & \multirow{3}{*}{$\begin{array}{l}\chi^{2} \text { test of } \\
\text { difference } \\
\text { between FDs } \\
\text { and } \\
\text { AEPs }(\text { prob. })^{5}\end{array}$} \\
\hline & & & & $F D s$ & & \\
\hline $\operatorname{code}^{1}$ & & $(n=153)$ & $(n=244)$ & rank & & \\
\hline 36 & Quality of information provided by management to auditor & 24.8 & 38.5 & $29=$ & $24=$ & $\begin{array}{l}6.473^{3} \\
(0.011) \\
\end{array}$ \\
\hline 46 & Level of non-audit fees from incumbent auditor & 24.8 & 28.7 & $29=$ & $32=$ & n.s. \\
\hline 9 & Capital issues of debt or equity convertibles & 24.8 & 23.4 & $29=$ & 37 & n.s. \\
\hline 16 & Related party transactions & 24.2 & 31.6 & 32 & 30 & n.s. \\
\hline 2 & $\begin{array}{l}\text { Contingent contracts (e.g., consignment stock, sale and } \\
\text { repurchase/leaseback, factoring etc.) }\end{array}$ & 22.2 & 30.3 & 33 & 31 & n.s. \\
\hline 29 & $\begin{array}{l}\text { Issues arising from the requirement to comply with the } \\
\text { Companies Acts and Accounting Standards not specifically } \\
\text { itemised in the questionnaire }\end{array}$ & 21.6 & 25.0 & 34 & 34 & n.s. \\
\hline 44 & Unexpected audit-related fees & 20.3 & 28.7 & 35 & $32=$ & n.s. \\
\hline 37 & Failure to meet agreed audit timetable by company & 19.6 & 45.9 & 36 & $17=$ & $\begin{array}{l}25.553^{3} \\
(0.000)\end{array}$ \\
\hline 28 & Maintenance of proper accounting records & 19.0 & 8.6 & 37 & 43 & $\begin{array}{l}9.548^{4} \\
(0.002)\end{array}$ \\
\hline 38 & Failure to meet agreed audit timetable by auditor & 18.3 & 5.7 & 38 & 46 & $\begin{array}{l}18.773^{4} \\
(0.000)\end{array}$ \\
\hline 42 & Ability to detect fraud and other irregularities & 17.0 & 28.3 & 39 & 35 & $\begin{array}{l}5.195^{3} \\
(0.023)\end{array}$ \\
\hline 45 & Attempts to renegotiate agreed audit fees & 16.3 & 20.9 & 40 & 39 & n.s. \\
\hline 39 & Time pressures caused by late adjustments from company & 15.0 & 38.5 & $41=$ & $24=$ & $\begin{array}{l}22.004^{3} \\
(0.000)\end{array}$ \\
\hline 17 & Environmental liabilities/contingencies & 15.0 & 20.5 & $41=$ & 40 & n.s. \\
\hline 40 & Time pressures caused by late adjustments from auditor & 14.4 & 7.0 & 43 & 45 & $\begin{array}{l}6.223^{4} \\
(0.013) \\
\end{array}$ \\
\hline 35 & $\begin{array}{l}\text { Information provided to, or other form of communication } \\
\text { with, a regulator (e.g., Bank of England, Financial Reporting } \\
\text { Review Panel, etc.) }\end{array}$ & 11.8 & 12.3 & 44 & 41 & n.s. \\
\hline 20 & Fraud and illegal acts & 11.1 & 11.1 & 45 & 42 & n.s. \\
\hline 6 & Brands & 5.9 & 8.2 & 46 & 44 & n.s. \\
\hline
\end{tabular}

Notes: 1. Issues are shown in decreasing frequency for the FD sample.

2. $\mathrm{FD}=$ finance director; $\mathrm{AEP}=$ audit partner

3. Issue which AEPs cite significantly more frequently than FDs.

4. Issue which AEPs cite significantly less frequently than FDs.

5. n.s. $=$ not significant at the $5 \%$ level. 
activity over the three year period could reasonably be described as high: four issues are cited by more than $50 \%$ of FD respondents and 12 issues are cited by more than $50 \%$ of AEP respondents.

Of the top ten discussion issues cited by FDs (AEPs), 4(4) relate to compliance, 1(2) relates to audit-related matters, 1(3) relates to accounting principles and practice, 2(1) relate to the balance sheet and 2(-) relate to disclosure. The high ranking of issues 30 (timing of implementation of new regulatory requirements), 31 (disclosure of directors' remuneration packages and stock options) and 33 (existence and composition of audit committee) is to be expected, given that they were new requirements and apply to all companies. In addition, the disclosure of directors' remuneration packages and stock options (ranked 2 and 3 by FDs and AEPs, respectively) is an extremely sensitive issue for directors, due to the media attention it attracts.

The high ranking of nature and content of management letters (ranked 3 and 2 by FDs and AEPs, respectively) is also to be expected. Management letters are one way in which value can be added to the audit, with points relating to internal controls and accounting policies being most valued by companies (Manson et al., 1994). ${ }^{7}$ Management letters can, however, include implicit or explicit criticism of the executive directors. In consequence, the high incidence of discussion can be seen as a behavioural response to the personal, sensitive nature of the issue.

It is also interesting to note some of the issues which do not rank highly. For example, despite the now widespread acceptance of the importance of accounting for the environment (Gray et al. 1993), environmental liabilities / contingencies rank a lowly 41 and 40 by FDs and AEPs, respectively, while, despite the well-documented expectation gap, ability to detect fraud and other irregularities ranks only 39 and 35 by FDs and AEPs, respectively. ${ }^{8}$

The rankings for the FD and AEP samples separately were very similar. The Spearman rank correlation between the FD and AEP rankings was very high $(\mathrm{r}=0.876 ; \mathrm{p}<0.0001)$, indicating a broad consensus in the responses of both groups. ${ }^{9}$ We investigated whether there was any significant association between discussion frequency and respondent type using $\chi^{2}$ tests (see final column of Table 4). Significant associations (the 5\% level is used throughout this paper) were found in 14 out of the 46 cases, with 11 issues being cited more frequently by AEPs and three issues being cited more frequently by FDs. The general tendency for AEPs to indicate more frequently than FDs that discussion took place is perhaps not surprising. We offer three interpretations of this, which are not necessarily mutually exclusive. First, the AEPs work effort relates primarily to issues concerning the production and audit of annual financial statements, whereas the responsibilities of FDs relate to a wider range of activities concerning the financial management of the company. This is likely to mean that the AEPs' recall of specific interactions will be better than that of the FDs. Second, AEPs' awareness of concerns regarding auditor independence may lead the AEPs to overstate (consciously or unconsciously) their involvement with directors and their impact upon the financial statements. Third, it is likely that, since the samples are not matched, the AEPs' responses relate to more difficult/ complex clients than those in the FD sample. This is because the AEPs' responses refer to their 'largest' listed company client (defined above), and company size is highly correlated with complexity (Pong and Whittington, 1994).

While a broad consensus between the responses of both groups is to be expected, a certain lack of agreement on specific issues (and hence less than perfect correlation) is also to be expected. Although FDs and AEPs can be expected, as professional accountants, to share many views, their employment context gives them a different set of motivations and priorities. In general, compared to FDs, AEPs can be expected to be more concerned with compliance with the regulatory framework and to emphasise technical accounting considerations rather more than commercial considerations in matters of judgment. Consequently, the importance (and hence recall) of specific interactions will vary across the groups according to their priorities. It is, therefore, not surprising that not only more issues are listed as interactions by AEPs, but also (to an extent) different issues.

Among the top ten issues shown in Table 4, four are cited significantly more frequently by AEPs. Our observations relating to issues below this are as follows. The three issues cited significantly more frequently by FDs occur at the lower end of the rankings (below 36 for both groups): maintenance of proper accounting records, 
failure to meet agreed audit timetable by auditor, and time pressures caused by late adjustments from auditor. It is to be expected that the first of these issues would be of direct concern to FDs (being their responsibility and not that of the auditor), while our findings in respect of the latter two issues (viewed in conjunction with those for the comparable issues relating to the company), reflect the different perceptions of the parties as to who caused 'the problem'.

RQ2: What issues are negotiated by FDs and AEPS and what is the incidence of these negotiations?

The frequency with which each of the 46 issues was the subject of negotiation between the auditor and auditee is reported in Table 5, whose format is identical to that of Table 4, with the addition of columns showing the comparable ranks from Table 4 (see columns two and three). The extent of negotiation is reasonably high: two issues are cited by more than $20 \%$ of FD respondents and eight issues are cited by more than $20 \%$ of AEP respondents. Of the top ten negotiation issues cited by FDs and AEPs, accounting principles and practice issues and audit-related issues dominate. The high rank of accounting issues 7 (reorganisation costs), 13 (fair values on acquisition), and 14 (reorganisation costs on acquisition) indicates that, despite FRS3, reported earnings can still be 'managed' to some degree - it has been suggested that the bottom line used by the City has simply moved down to 'super-exceptionals' (Griffiths, 1996, ch.1). The high rank of accounting issues 21 and 26 (stock and work-in-progress and deferred tax) may be attributed to their highly subjective nature relative to other accounting issues (Griffiths, 1996, chs. 5 and 13). As with discussion, the FD and AEP samples have very similar rankings of the 46 issues in terms of the incidence of negotiation (Spearman rank correlation $=0.854$; $\mathrm{p}<0.0001){ }^{10}$

It is interesting to compare the discussion rankings from Table 4 with the Table 5 rankings. Three issues are ranked by both groups more than 20 places higher in Table 5 compared to Table 4, and these include three issues relating to audit fees. Thus, the critical importance of fee issues in audit relationships which has been documented in previous studies is supported (Beattie and Fearnley, 1995).
The association between negotiation frequency and respondent type was investigated using $\chi^{2}$ tests (see final column of Table 5). Significant associations were found in 29 out of the 46 issues, all of which were cited significantly more frequently by AEPs than FDs. Thus, significant differences between AEP and FD responses with respect to negotiation occurred for ten more issues than for discussion, indicating that the divergence between FD and AEP views is greater at this level of interaction. ${ }^{11}$

\section{RQ3: What issues are of most importance to respon- dents and what events are associated with these interactions?}

It must be recognised that the frequency of interactions across the samples does not necessarily reflect the importance of these interactions for individual respondents. To establish the relative importance to each respondent of the issues which they cited, we asked respondents to identify the three issues of most significance to them. Among the top ten issues for each sample group, ranked on the basis of total citations by individuals across the top three slots, there are seven common issues: group matters, stock and work-in-progress, timing of implementation of new regulatory requirements (FRSs, Cadbury, etc.), reorganisation costs, statements in the annual report concerning compliance with the Cadbury Code of Best Practice, goodwill, and going concern. The three issues which appear only in the FDs' top ten are: off-balance sheet items, nature and content of management letters, and unexpected auditrelated fees, while the three issues which appear only in the AEPs' top ten are: issues arising from the requirement to comply with the Companies Acts and Accounting Standards not specifically itemised in the questionnaire, debtors, and deferred tax assets/liabilities. This reflects the differing objectives, attitudes and, hence, perspectives of both groups.

This contrasts starkly with the results in Table 5 . It is clear that the correlation between interaction frequency and interaction importance (measured as the importance of the issue to the individual) is low. In particular, although the issues of going concern and statements in the annual report concerning compliance with the Cadbury Code of Best Practice do not rank highly for either group with respect to negotia- 


\section{Table 5: Frequency of Negotiation of Issues}

\begin{tabular}{|c|c|c|c|c|c|c|c|c|}
\hline \multirow[b]{2}{*}{$\begin{array}{l}\text { Issue } \\
\text { code }^{1}\end{array}$} & \multicolumn{2}{|c|}{$\begin{array}{l}\text { Ranks from } \\
\text { Table } 4\end{array}$} & \multirow[b]{2}{*}{ Issue } & \multirow[b]{2}{*}{$\underset{(n=153)}{F D s}$} & \multirow[b]{2}{*}{$\begin{array}{c}A E P S \\
(n=244)\end{array}$} & \multirow[b]{2}{*}{$\begin{array}{l}\text { FDs } \\
\text { rank }\end{array}$} & \multirow[b]{2}{*}{$\begin{array}{l}\text { AEPS } \\
\text { rank }\end{array}$} & \multirow{2}{*}{$\begin{array}{l}\chi^{2} \text { test of difference } \\
\text { between FDs and } \\
A E P S \text { (prob.) } \text { ) }^{3,6}\end{array}$} \\
\hline & $F D$ & $A E P$ & & & & & & \\
\hline 44 & 35 & $32=$ & Unexpected audit-related fees ${ }^{4}$ & 24.2 & 27.5 & 1 & $3=$ & n.s. \\
\hline 46 & $29=$ & $32=$ & Level of non-audit fees from incumbent auditor ${ }^{4}$ & 20.3 & 20.1 & 2 & $7=$ & n.s. \\
\hline 13 & $13=$ & 9 & Group matters: fair values on acquisition & 17.0 & 27.5 & 3 & $3=$ & $\begin{array}{l}4.587 \\
(0.032)\end{array}$ \\
\hline 45 & 40 & 39 & Attempts to renegotiate agreed audit fees ${ }^{4}$ & 16.3 & 21.3 & 4 & 6 & n.s. \\
\hline 7 & 5 & 10 & Reorganisation costs & 15.0 & 34.4 & $5=$ & 1 & $\begin{array}{l}16.242 \\
(0.000)\end{array}$ \\
\hline 21 & 10 & $15=$ & Stock and work-in-progress & 15.0 & 20.1 & $5=$ & $7=$ & n.s. \\
\hline 41 & 3 & 2 & Nature and content of management letters & 10.5 & 30.7 & 7 & 2 & $\begin{array}{l}22.366 \\
(0.000)\end{array}$ \\
\hline 30 & 1 & 1 & $\begin{array}{l}\text { Timing of implementation of new regulatory } \\
\text { requirements (FRSs, Cadbury, etc.) }\end{array}$ & 9.8 & 18.9 & 8 & $9=$ & $\begin{array}{c}6.122 \\
(0.013)\end{array}$ \\
\hline 26 & $6=$ & 7 & Deferred tax assets/liabilities & 8.5 & 18.9 & $9=$ & $9=$ & $\begin{array}{l}8.060 \\
(0.005)\end{array}$ \\
\hline 10 & 12 & 12 & Group matters: merger or acquisition accounting & 8.5 & - & $9=$ & 11 & $\begin{array}{l}5.341 \\
(0.021)\end{array}$ \\
\hline 14 & 24 & 20 & Group matters: reorganisation costs on acquisition & - & 22.1 & 11 & 5 & $\begin{array}{l}11.467 \\
(0.001)\end{array}$ \\
\hline 5 & $13=$ & 4 & Goodwill & 7.2 & 17.6 & $12=$ & 12 & $\begin{array}{l}8.799 \\
(0.003)\end{array}$ \\
\hline 8 & $26=$ & 38 & Prior year adjustments & 7.2 & 8.2 & $12=$ & 30 & n.s. \\
\hline 3 & $21=$ & 14 & Off-balance sheet items & 5.9 & 17.2 & $14=$ & 13 & $\begin{array}{l}10.457 \\
(0.001)\end{array}$ \\
\hline 11 & 20 & 22 & Group matters: subsidiary undertakings & 5.9 & 11.9 & $14=$ & 23 & $\begin{array}{c}3.889 \\
(0.049) \\
\end{array}$ \\
\hline 24 & 23 & $32=$ & Investments & 5.9 & 11.1 & $14=$ & 24 & n.s. \\
\hline 37 & 36 & $17=$ & Failure to meet agreed audit timetable by company & 5.2 & 14.3 & $17=$ & $17=$ & $\begin{array}{c}7.941 \\
(0.005)\end{array}$ \\
\hline 22 & 25 & 28 & Debtors & 5.2 & 13.5 & $17=$ & $19=$ & $\begin{array}{c}6.953 \\
(0.008)\end{array}$ \\
\hline 23 & $26=$ & $26=$ & Liabilities & 4.6 & 14.8 & 19 & $15=$ & $\begin{array}{l}10.170 \\
(0.001)\end{array}$ \\
\hline 31 & 2 & 3 & $\begin{array}{l}\text { Statements in the annual report concerning compliance } \\
\text { with the Cadbury Code of Best Practice re disclosure of } \\
\text { directors' remuneration packages and stock options }\end{array}$ & 3.9 & 15.2 & $20=$ & 14 & $\begin{array}{l}12.396 \\
(0.000) \\
\end{array}$ \\
\hline 29 & 34 & 34 & $\begin{array}{l}\text { Issues arising from the requirement to comply with } \\
\text { the Companies Acts and Accounting Standards not } \\
\text { specifically itemised in the questionnaire }\end{array}$ & 3.9 & 14.8 & $20=$ & $15=$ & $\begin{array}{l}11.365 \\
(0.001)\end{array}$ \\
\hline 12 & 18 & $26=$ & Group matters: associated undertakings & 3.9 & 10.7 & $20=$ & 25 & $\begin{array}{l}5.726 \\
(0.017)\end{array}$ \\
\hline 36 & $29=$ & $24=$ & $\begin{array}{l}\text { Quality of information provided by management } \\
\text { to auditor }\end{array}$ & 3.9 & 9.0 & $20=$ & 27 & n.s. \\
\hline 34 & 17 & 6 & Stock Exchange reporting requirements & 3.9 & 6.6 & $20=$ & $32=$ & n.s. \\
\hline 33 & 4 & 8 & $\begin{array}{l}\text { Statements in the annual report concerning compliance } \\
\text { with the Cadbury Code of Best Practice re existence and } \\
\text { composition of audit committee }\end{array}$ & 3.3 & 3.7 & $20=$ & 38 & n.s. \\
\hline 32 & 9 & 12 & $\begin{array}{l}\text { Statements in the annual report concerning compliance } \\
\text { with the Cadbury Code of Best Practice re existence and } \\
\text { composition of remuneration committee }\end{array}$ & 3.9 & 1.6 & $20=$ & 42 & n.s. \\
\hline 1 & 11 & 11 & Operating and finance leases & 3.3 & 14.3 & $27=$ & $17=$ & $\begin{array}{l}12.691 \\
(0.000)\end{array}$ \\
\hline 25 & 19 & 23 & Fixed assets & 3.3 & 13.5 & $27=$ & $19=$ & $\begin{array}{l}11.389 \\
(0.001)\end{array}$ \\
\hline
\end{tabular}


Table 5: continued

\begin{tabular}{|c|c|c|c|c|c|c|c|c|}
\hline \multirow[b]{2}{*}{$\begin{array}{l}\text { Issue } \\
\text { code }^{1}\end{array}$} & \multicolumn{2}{|c|}{$\begin{array}{l}\text { Ranks from } \\
\text { Table } 4\end{array}$} & \multirow[b]{2}{*}{ Issue } & \multirow[b]{2}{*}{$\begin{array}{c}\text { FDs } \\
(n=153)\end{array}$} & \multirow[b]{2}{*}{$\begin{array}{c}\text { AEPS } \\
(n=244)\end{array}$} & \multirow[b]{2}{*}{$\begin{array}{l}\text { FDs } \\
\text { rank }\end{array}$} & \multirow[b]{2}{*}{$\begin{array}{l}\text { AEPS } \\
\text { rank }\end{array}$} & \multirow{2}{*}{$\begin{array}{l}\chi^{2} \text { test of difference } \\
\text { between } F D \text { s and } \\
A E P S \text { (prob.). }\end{array}$} \\
\hline & $F D$ & $A E P$ & & & & & & \\
\hline 2 & 33 & 31 & $\begin{array}{l}\text { Contingent contracts (e.g., consignment stock, sale and } \\
\text { repurchase/leaseback, factoring etc.) }\end{array}$ & 3.3 & 12.3 & $27=$ & 22 & $\begin{array}{c}9.075 \\
(0.003)\end{array}$ \\
\hline 27 & $21=$ & $17=$ & $\begin{array}{l}\text { Deferred pension or other retirement benefit assets/ } \\
\text { liabilities }\end{array}$ & 3.3 & 10.2 & $27=$ & 26 & $\begin{array}{c}6.444 \\
(0.011)\end{array}$ \\
\hline 4 & 15 & 19 & Regularity of fixed asset revaluations & 3.3 & 6.6 & $27=$ & $32=$ & n.s. \\
\hline 39 & $41=$ & $24=$ & Time pressures caused by late adjustments from company & $\begin{array}{ll} & 2.6 \\
\end{array}$ & 13.1 & $32=$ & 21 & $\begin{array}{l}12.293 \\
(0.000)\end{array}$ \\
\hline 15 & 8 & 21 & Going concern & 2.6 & 5.7 & $32=$ & $34=$ & n.s. \\
\hline 40 & 43 & 45 & Time pressures caused by late adjustments from auditor & 2.6 & 2.5 & $32=$ & $39=$ & n.s. \\
\hline 9 & $29=$ & 37 & Capital issues of debt or equity convertibles & 2.0 & 8.6 & $35=$ & $28=$ & $\begin{array}{c}4.943 \\
(0.026)\end{array}$ \\
\hline 19 & $6=$ & $15=$ & Post balance sheet events & 2.0 & 7.8 & $35=$ & 31 & $\begin{array}{c}6.207 \\
(0.013)\end{array}$ \\
\hline 28 & 37 & 43 & Maintenance of proper accounting records & 2.0 & 0.4 & $35=$ & $43=$ & n.s. \\
\hline 43 & 16 & 5 & Extent of audit of internal control & 1.3 & 5.7 & $38=$ & $34=$ & $\begin{array}{l}4.755 \\
(0.029)\end{array}$ \\
\hline 16 & 32 & 30 & Related party transactions & 1.3 & 5.3 & $38=$ & 36 & $\begin{array}{l}4.165 \\
(0.041)\end{array}$ \\
\hline 18 & 28 & 29 & Contingencies other than environmental & 0.7 & 8.6 & $40=$ & $28=$ & $\begin{array}{l}11.334 \\
(0.001)\end{array}$ \\
\hline 38 & 38 & 46 & Failure to meet agreed audit timetable by auditor & 0.7 & 0.4 & $40=$ & $43=$ & n.s. \\
\hline 6 & 46 & 44 & Brands & 0.7 & 0.4 & $40=$ & $43=$ & n.s. \\
\hline 17 & $41=$ & 40 & Environmental liabilities/contingencies & 0.0 & 4.5 & $43=$ & 37 & $(0.008)^{5}$ \\
\hline 35 & 44 & 41 & $\begin{array}{l}\text { Information provided to, or other form of } \\
\text { communication with, a regulator (e.g., Bank of } \\
\text { England, Financial Reporting Review Panel, etc.) }\end{array}$ & 0.0 & 2.5 & $43=$ & $39=$ & $(0.086)^{5}$ \\
\hline 42 & 39 & 35 & Ability to detect fraud and other irregularities & 0.0 & 2.0 & $43=$ & 41 & n.s. \\
\hline 20 & 45 & 42 & Fraud and illegal acts & 0.0 & 0.0 & $43=$ & 46 & - \\
\hline Notes: & $\begin{array}{l}\text { 1. Iss } \\
\text { 2. FD } \\
\text { 3. All } \\
\text { 4. Iss } \\
\text { 5. Fis } \\
\text { ha } \\
\text { 6. n.s }\end{array}$ & $\begin{array}{l}\text { gnific } \\
\text { wher } \\
r^{\prime} \text { s ex } \\
\text { an ex } \\
\text { not s }\end{array}$ & $\begin{array}{l}\text { hown in decreasing frequency for the FD sample. } \\
\text { e director; AEP = audit partner } \\
\text { ant differences relate to issues cited more frequently by AEP } \\
\text { frequency of negotiation is } \geq 20 \text { ranks higher than frequen } \\
\text { act probability (two-tailed) reported, since chi-square may n } \\
\text { bected frequency }<5 \text { (Siegel and Castellan, 1988, p. 123). } \\
\text { gnificant at the } 5 \% \text { level. }\end{array}$ & $\begin{array}{l}\text { EPs than } \\
\text { ncy of dis } \\
\text { not be a }\end{array}$ & $\begin{array}{l}\text { Ds. } \\
\text { cussion } \mathrm{fo} \\
\text { alid test }\end{array}$ & $\begin{array}{l}\text { th gro } \\
\geq 20 \%\end{array}$ & the cells & \\
\hline
\end{tabular}

tion frequency, any interactions which do occur assume a very high level of importance.

Respondents were asked whether any of these three most important issues led to: the possibility of a qualified audit opinion, a second opinion being sought from within the firm (AEP sample only) or from a third party (e.g., lawyer, regulator, or other audit firm), consideration of a change in auditor by either party, and/or an actual change in auditor (FD sample only). Responses are summarised in Table 6. The client is aware of the possibility of a qualified audit report in only six instances, compared to 62 for the AEP sample. These figures represent 2.4\% and $9.5 \%$ of the total number of issues cited by each group, respectively. This suggests that companies may be unaware that a qualified audit opinion is being considered.

It was also found that the level of internal consultation by AEPs is high, standing at 442 $(67.9 \%)$, with the issue most commonly involved being reorganisation costs. There is evidence of both parties seeking external second opinions, due to either uncertainty or, for the FD sample, opinion-shopping. Opinion-shopping by auditees is also one explanation of the consideration of a change in auditors by auditees. The underlying issues referred to in Table 6 cover a 
very wide range, indicated by the low citation frequency for even the most frequently cited issue. Fee issues continue, however, to appear at the forefront of auditor change consideration.

\section{Table 6: Events Triggered by the Three Most Important Issues}

\begin{tabular}{lcc}
\hline \multirow{2}{*}{ Event } & \multicolumn{2}{c}{ No. of reported cases } \\
\cline { 2 - 3 } & FDs & $A E P S$ \\
\hline Possibility of a qualified audit report & $6^{1}$ & $62^{1}$ \\
\hline $\begin{array}{l}\text { Second opinion sought from: } \\
\text { within firm }\end{array}$ & $\mathrm{N} / \mathrm{A}$ & $442^{3}$ \\
$\quad$ third party & $18^{2}$ & $27^{4}$ \\
\hline $\begin{array}{l}\text { Consideration of auditor change by: } \\
\text { auditor resignation } \\
\text { client company }\end{array}$ & $\mathrm{N} / \mathrm{A}$ & $12^{6}$ \\
\hline
\end{tabular}

Notes: 1. Most frequently cited issue was going concern (2 citations by FDs and 8 by AEPs).

2. Most frequently cited issue was timing of implementation of new regulatory requirements (3 citations).

3. Most frequently cited issue was reorganisation costs (50 citations).

4. Most frequently cited issues were: contingencies other than environmental and deferred pension or other post retirement benefit assets/liabilities (3 citations each).

5. Most frequently cited issue was unexpected audit-related fees (5 citations).

6. Most frequently cited issue was attempts to renegotiate agreed audit fees (2 citations).

7. Most frequently cited issue was level of nonaudit fees from incumbent auditor (3 citations).

The widespread practice of auditors seeking a second opinion, together with their willingness to consider audit qualification, can be viewed as prima facie audit quality indicators.

RQ4: What is the incidence of changes to the accounting numbers or disclosures arising from the audit process?

Out of the 46 issues examined above, 35 could give rise to changes in the accounting numbers and/or disclosures, whereas the 11 audit-related matters could not. The frequency with which such changes arose from discussion and/or negotiation is reported in Table 7. Once again, our initial impression is that the audit process has a significant impact upon corporate financial statements: more than 10\% of FDs indicated a change to the accounting numbers for 3 issues, while more than $10 \%$ of AEPs indicated a change to the accounting numbers for 13 issues. The corresponding number of issues were 10 and 27, respectively, for a change to disclosures. It is noticeable that AEPs indicate a greater amount of change than FDs. We attribute this to the three reasons identified above in relation to discussion frequencies.

Naturally, the top ten issues resulting in changes to the accounting numbers relate to accounting principles and practice or balance sheet areas, whereas the top ten issues resulting in a change to disclosures also included three compliance issues. The Spearman rank correlation between the FD and AEP rankings was very high for both changes to the accounting numbers and to the disclosures $(r=0.865$; $\mathrm{p}<0.0001$ and $\mathrm{r}=0.735 ; \mathrm{p}<0.0001$, respectively).

Significant associations between reported changes and respondent type occurred for the majority of issues, in all cases AEPs reporting changes significantly more frequently than FDs. These findings demonstrate an interesting difference in the perceptions of both parties, with auditors believing that they have more influence upon financial reporting outcomes than directors admit to.

\section{RQ5: What are the typical patterns of interaction progression?}

Thus far in the analysis, the incidence and nature of the various forms of interaction which can occur have been considered in isolation from each other. It might be expected that the normal progression of interaction between an auditor and their client company would be from none, to discussion, then negotiation, and then change to the accounting numbers and/or disclosures, with the progression ending at any of the interim stages. It is also possible, however, for a change to result from discussion only, i.e., the negotiation stage is not required, or for interaction to start at the negotiation stage. The occurrence/non-occurrence of discussion, negotiation, change to the accounting numbers, and change to the disclosures gives rise to 16 (i.e., $2^{4}$ ) possible combinations of these four activities/events by each respondent for 35 of the issue set. There are four possible combinations for the remaining 11 audit-related issues where change to the financial statements was not involved. The frequency distribution of responses across these combinations, aggregated across issues, is given in Table 8 for each respondent group.

The response patterns of the two groups appear similar, although a $\chi^{2}$ test indicates that 


\section{Table 7: Frequency of Changes to Accounting Numbers and Disclosures Resulting from Discussion and Negotiation}

Panel A: Change to accounting numbers

\begin{tabular}{|c|c|c|c|c|c|c|c|c|}
\hline \multirow{2}{*}{$\begin{array}{l}\text { Issue } \\
\text { code }^{1}\end{array}$} & \multirow[b]{2}{*}{ Issue } & \multicolumn{2}{|c|}{$\begin{array}{l}\text { Ranks from } \\
\text { Table } 5\end{array}$} & \multicolumn{2}{|c|}{$\begin{array}{l}\% \text { indicating change to } \\
\text { accounting numbers }\end{array}$} & \multirow{2}{*}{$\begin{array}{l}\text { FDs } \\
\text { rank }\end{array}$} & \multirow{2}{*}{$\begin{array}{c}\text { AEPS } \\
\text { rank }\end{array}$} & \multirow{2}{*}{$\begin{array}{l}\chi^{2} \text { test of } \\
\text { difference } \\
\text { between } F D \text { and } \\
A E P \text { samples }{ }^{3,4}\end{array}$} \\
\hline & & FDs & $A E P_{S}$ & $(n=153)$ & $(n=244)$ & & & \\
\hline 21 & Stock and work-in-progress & $5=$ & $7=$ & 12.4 & 18.4 & 1 & 7 & n.s. \\
\hline 8 & Prior year adjustments & $12=$ & - & 11.1 & - & 2 & - & n.s. \\
\hline 13 & Group matters: fair values on acquisition & 3 & $3=$ & 10.5 & 27.9 & 3 & 2 & $14.999^{* * *}$ \\
\hline 7 & Reorganisation costs & $5=$ & 1 & 9.2 & 35.7 & 4 & 1 & $32.351^{* * *}$ \\
\hline 5 & Goodwill & $12=$ & 12 & 7.2 & 21.7 & $5=$ & 3 & $14.813^{* * *}$ \\
\hline 26 & Deferred tax assets/liabilities & $9=$ & $9=$ & 7.2 & 18.9 & $5=$ & 6 & $10.502^{* * *}$ \\
\hline 1 & Operating and finance leases & $27=$ & $17=$ & 7.2 & 17.6 & $5=$ & 8 & $8.667^{* *}$ \\
\hline 3 & Off-balance sheet items & $14=$ & 13 & 6.5 & 15.2 & 8 & $9=$ & $6.454^{*}$ \\
\hline 10 & Group matters: merger or acquisition accounting & $9=$ & 11 & 5.2 & 20.1 & 9 & 4 & $14.318^{\star * *}$ \\
\hline 14 & Group matters: reorganisation costs on acquisition & 11 & 5 & 4.6 & 19.3 & $10=$ & 5 & $14.467^{\text {***}}$ \\
\hline 11 & Group matters: subsidiary undertakings & $14=$ & 23 & 4.6 & - & $10=$ & - & n.s. \\
\hline 23 & Liabilities & 19 & $15=$ & - & 15.2 & - & $9=$ & $14.161^{\text {***}}$ \\
\hline
\end{tabular}

Panel B: Change to disclosures

\begin{tabular}{|c|c|c|c|c|c|c|c|c|}
\hline \multirow[b]{2}{*}{$\begin{array}{l}\text { Issue } \\
\text { code }\end{array}$} & \multirow[b]{2}{*}{ Issue } & \multicolumn{2}{|c|}{$\begin{array}{l}\text { Ranks from } \\
\text { Table } 5\end{array}$} & \multicolumn{2}{|c|}{$\begin{array}{l}\% \text { indicating change to } \\
\text { disclosures }\end{array}$} & \multirow[b]{2}{*}{$\begin{array}{l}\text { FDs } \\
\text { rank }\end{array}$} & \multirow[b]{2}{*}{$\begin{array}{l}\text { AEPs } \\
\text { rank }\end{array}$} & \multirow{2}{*}{$\begin{array}{l}\chi^{2} \text { test of } \\
\text { difference } \\
\text { between FDs and } \\
A E P S^{3,4}\end{array}$} \\
\hline & & FDs & $A E P S$ & $\begin{array}{c}F D s \\
(n=153)\end{array}$ & $\begin{array}{c}A E P S \\
(n=244)\end{array}$ & & & \\
\hline 30 & $\begin{array}{l}\text { Timing of implementation of new regulatory } \\
\text { requirements (FRSs, Cadbury, etc.) }\end{array}$ & 8 & $9=$ & 29.4 & 49.6 & 1 & 1 & $14.751^{* * *}$ \\
\hline 31 & $\begin{array}{l}\text { Statements concerning Cadbury compliance re directors' } \\
\text { remuneration packages and stock options }\end{array}$ & $20=$ & 14 & 26.1 & 42.2 & 2 & 2 & $9.375^{* *}$ \\
\hline 33 & $\begin{array}{l}\text { Statements concerning Cadbury compliance re existence } \\
\text { and composition of audit committee }\end{array}$ & $20=$ & 38 & 17.0 & - & 3 & - & n.s. \\
\hline 32 & $\begin{array}{l}\text { Statements concerning Cadbury compliance re existence } \\
\text { and composition of remuneration committee }\end{array}$ & $20=$ & 42 & 15.0 & - & 4 & - & n.s. \\
\hline 15 & Going concern & $32=$ & $34=$ & 13.7 & - & $5=$ & - & n.s. \\
\hline 7 & Reorganisation costs & $5=$ & 1 & 13.7 & 34.0 & $5=$ & 3 & $18.182^{* * *}$ \\
\hline 13 & Group matters: fair values on acquisition & 3 & $3=$ & 12.4 & 28.7 & 7 & 4 & $12.438^{\star * *}$ \\
\hline 3 & Off-balance sheet items & $14=$ & 13 & - & 28.3 & - & 5 & $23.578^{* * *}$ \\
\hline 1 & Operating and finance leases & $27=$ & $17=$ & 11.8 & 24.6 & $8=$ & 7 & $9.742^{* *}$ \\
\hline 34 & Stock Exchange reporting requirements & $20=$ & $32=$ & 11.8 & 23.4 & $8=$ & 8 & $6.906^{* *}$ \\
\hline 5 & Goodwill & $12=$ & 12 & - & 26.2 & - & 6 & $24.227^{* * *}$ \\
\hline 10 & Group matters: merger or acquisition accounting & $9=$ & 11 & 11.8 & 23.0 & $8=$ & 9 & $6.168^{*}$ \\
\hline 27 & $\begin{array}{l}\text { Deferred pension or other post retirement benefit } \\
\text { assets/liabilities }\end{array}$ & $27=$ & 26 & - & 22.1 & - & 10 & $13.609^{* * *}$ \\
\hline
\end{tabular}

Notes: 1. Issues are shown in decreasing frequency for the FD sample.

2. $\mathrm{FD}=$ finance director; $\mathrm{AEP}=$ audit partner

3. Issue which AEPs cite significantly more frequently than FDs.

4. n.s. $=$ not significant at the $5 \%$ level; ${ }^{*}=$ sig. at $5 \% ;^{* *}=$ sig. at $1 \%$; and ${ }^{* * *}=$ sig. at $0.1 \%$. 
Table 8: Frequency Distribution of Interaction Combinations Between Auditors and Auditees

\begin{tabular}{cccccccccc}
\hline $\begin{array}{c}\text { Respondent } \\
\text { group }\end{array}$ & $\begin{array}{c}\text { No } \\
\text { interaction }\end{array}$ & $\begin{array}{c}\text { Discussion } \\
\text { only }\end{array}$ & $\begin{array}{c}\text { Discussion and } \\
\text { negotiation; } n \text { iscussion } \\
\text { change }\end{array}$ & $\begin{array}{c}\text { Discussion } \\
\text { and } \\
\text { negotiation } \\
\text { and change }\end{array}$ & $\begin{array}{c}\text { Change without } \\
\text { either } \\
\text { discussion or } \\
\text { negotiation }\end{array}$ & $\begin{array}{c}\text { Change with } \\
\text { negotiation } \\
\text { only }\end{array}$ & $\begin{array}{c}\text { Negotiation } \\
\text { only }\end{array}$ & Total \\
\hline $\begin{array}{c}\text { FD sample: } \\
\text { Number }\end{array}$ & 4309 & 1807 & 84 & 383 & 76 & 15 & 103 & 137 & 6914 \\
\hline$\%$ & 62.3 & 26.2 & 1.2 & 5.5 & 1.1 & 0.2 & 1.5 & 2.0 & 100.0 \\
\hline $\begin{array}{c}\text { AEP sample: } \\
\text { Number }\end{array}$ & 6428 & 2522 & 383 & 916 & 557 & 0 & 253 & 148 & 112071 \\
\hline$\%$ & 57.3 & 22.5 & 3.4 & 8.2 & 5.0 & 0.0 & 2.3 & 1.3 & 100.0 \\
\hline
\end{tabular}

Note 1: This grand total is less than the combined number of respondents * 46 issues $=18,262$, since issues specifically reported not applicable have been excluded.

the response patterns are significantly different. For the FD (AEP) group, 37.7\% (42.7\%) of issues resulted in some interaction or change to the financial statements. It is interesting to note that $5.5 \%(8.2 \%)$ of issues result in change to the financial statements following discussion only. In the 400 (1341) cases where the negotiation stage was reached, $55 \%(40 \%)$ resulted in no change and $45 \%(60 \%)$ resulted in change, providing evidence of the auditors' influence on the financial statements. ${ }^{12}$ The existence of an audit committee was not associated with this outcome across both groups: change occurred in $56 \%$ of cases where no audit committee existed and in $57 \%$ of cases where an audit committee did exist, suggesting that, in practice, audit committees may not have some of the potential benefits identified in the Cadbury Report (1992) $\left(\chi^{2}=0.050\right)$.

RQ6: What is the relationship, if any, between the frequency of discussions and negotiations and (i) the existence of an audit committee, (ii) audit tenure, and (iii) level of non-audit fees paid to auditor?

Our data permits exploration of the link (if any) between three features of the auditor-client relationship and the nature and extent of interaction. These three features are the existence of an audit committee, duration of the auditorclient relationship, and the level of non-audit to audit fees paid to the incumbent.

The relationship between discussion frequency and existence of audit committee, was investigated for each sample using $\chi^{2}$ tests. Audit committees have in recent years been seen as a key corporate governance mechanism (in the US, Treadway Committee, 1987; AICPA, 1990; NYSE/NASD, 1999; and, in the UK, Cadbury Report, 1992; APB, 1994). Of the FD (AEP) respondents, $89 \%$ and $90 \%$, respectively, indicated that an audit committee existed..$^{13}$

We expected that audit committees would, ceteris paribus, generate greater levels of discussion, since financial reporting and the company's relationship with its external auditor are primary areas of concern to such committees. The Cadbury Report (1992) is typical of the literature in this area in not offering an explicit statement as to the purpose of such committees. This can, however, be inferred from the list of benefits of audit committee establishment. ${ }^{14}$ Our expectations were broadly realised. For the FD (AEP) sample, 12 (14) significant associations were found, 11 (10) of which were positive and only 1 (4) of which was negative. In general, therefore, there was a positive association between audit committee existence and level of discussion. Of course, audit committees are more likely to be found in large companies and company size is highly correlated with complexity (Pong and Whittington, 1994), hence the audit committee variable may be capturing related factors.

The relationship between negotiation frequency and existence of an audit committee was also examined for each sample, again using $\chi^{2}$ tests. The number of significant associations is less than for discussion across both respondent types. Our findings with respect to the impact of an audit committee we initially found to be surprising, since in nearly all cases the negotiation frequency of auditees with an audit committee was significantly less than those without. For the 
FD (AEP) sample, 5 (7) significant associations were found, 0 (1) of which was positive and 5 (6) of which were negative. Although these findings provide no direct evidence of audit committee effectiveness, taken in conjunction with our results concerning discussion, they suggest that audit committees are successful in reducing the confrontational intensity of interactions between auditors and auditees (i.e., they increase the level of discussion thereby reducing the level of negotiation). ${ }^{15}$

The duration of auditor-client alignments has several potential effects. While long-term relationships avoid high start-up costs, there is a danger that the ongoing economic dependence compromises auditor independence and/or that the auditor becomes 'stale'. Such stagnation is likely to result in less interaction. To investigate this issue, we used three alternative measures of relationship duration. First, we partitioned the samples into two groups, depending on whether the auditor appointment had existed more than ten years or less than or equal to ten years, and compared the mean number of issues cited for each of the four forms of interaction using twotailed t-tests. There were no significant differences (at the 5\% level) for any form of interaction in either sample, with the exception that there was significantly more discussion for long-term relationships in the FD sample $(t=-$ 2.12; $\mathrm{p}=0.036$ ). ${ }^{16}$ Second, we regressed (using simple OLS regression) the mean number of issues cited for each of the four forms of interaction against the number of years for which the same partner had signed the audit opinion. ${ }^{17}$ This variable was not significant at the 5\% level for either sample for any form of interaction. Third, we repeated these regressions using the number of years for which the same partner had been the 'main point of contact' as regressor. This variable was not significant at the $5 \%$ level for any form of interaction in either sample. Thus, overall, there is no evidence of audit stagnation associated with long-term relationships.

Since the 1970s, concerns have been expressed that the joint provision of non-audit and audit services increases the economic dependence of the auditor on the client and potentially impairs auditor independence (Metcalf Committee, 1976; POB, 1986). We interpret the level of interaction as a crude indicator of auditor independence; specifically, we suggest that if auditor independence is compromised, less negotiation and change will occur. In the FD sample, the number of issues cited as involving negotiation and change to the financial statements was regressed (using simple OLS regression) against the ratio of non-audit to audit fees paid to the incumbent (i.e., three separate regressions). No significant results (at the 5\% level) were found. In the AEP sample, the fee data available permitted the creation of only a three-class ordinal variable; non-audit fees in higher/same/lower fee band than audit fees. Using a general linear model (one-way ANOVA for unbalanced data), no significant results (at the $5 \%$ level) between the three groups' level of interaction emerged.

\section{RQ7: What are the observations of the individual respondents about the interaction process and its outcomes?}

Respondents were invited to comment on the process and the outcome of interactions and negotiations referred to in the questionnaire. They were also asked for their perceptions of the main factors influencing the outcomes. One hundred and eleven AEPs $(45 \%$ of total AEP respondents) and $39 \mathrm{FDs}(25 \%$ of total FD respondents) made a wide range of comments, some connected only loosely to the open-ended question posed. Using content analysis, three main categories were identified: no apparent conflict; attitudes to the regulatory framework; and influences on the outcomes of negotiations. All comments were coded into these categories. Each category was further divided into a small number of sub-categories. The categories and the number of responses for each sub-category are shown in Table 9.

As can be observed the response patterns in each sub-category vary considerably for FDs and AEPs. This emphasises the differing perspectives of each respondent group. The much higher proportion of AEPs than FDs making comments suggests a higher level of interest in the subject from AEPs, which is apparent from other response patterns in the questionnaire.

Category one (no apparent conflict) contains the highest overall number of comments, particularly from the FDs. Those in sub-category 1.1 (no real problems experienced) suggest that few issues have arisen:

'Our accounts are very straightforward with no contentious issues arising. We comply with all required disclosures' (FD). 


\section{Table 9: Summary of Individual Comments on the Interaction Process}

\begin{tabular}{|c|c|c|c|c|c|}
\hline \multirow[t]{2}{*}{ Category } & \multirow[t]{2}{*}{ Categories and sub-categories } & \multicolumn{2}{|c|}{$\operatorname{AEPs}(n=111)$} & \multicolumn{2}{|c|}{ FDs $(n=39)$} \\
\hline & & No. & $\begin{array}{c}\% \text { of } \\
\text { respondents } \\
\text { commenting }\end{array}$ & No. & $\begin{array}{l}\% \text { of } \\
\text { respondents } \\
\text { commenting }\end{array}$ \\
\hline 1 & No apparent conflict & & & & \\
\hline 1.1 & No real problems experienced & 4 & 3.6 & 6 & 15.4 \\
\hline 1.2 & Co-operative and interactive relationship & 26 & 25.2 & 14 & 35.9 \\
\hline \multirow[t]{2}{*}{1.3} & Problems discussed and resolved at an early stage & 32 & 28.8 & 9 & 23.0 \\
\hline & Sub-total & 62 & 55.9 & 29 & 74.4 \\
\hline 2 & Attitudes to the regulatory framework & & & & \\
\hline 2.1 & Company attitude to compliance & 30 & 27.0 & 5 & 12.8 \\
\hline \multirow[t]{2}{*}{2.2} & Comments on regulatory framework & 16 & 14.4 & 3 & 7.7 \\
\hline & Sub-total & 46 & 41.4 & 8 & 20.5 \\
\hline 3 & Influences on outcomes of negotiations & & & & \\
\hline 3.1 & Comments on more difficult interactions & 27 & 24.3 & 6 & 15.3 \\
\hline 3.2 & Involvement of audit committee and other directors & 12 & 10.8 & - & - \\
\hline \multirow[t]{3}{*}{3.3} & Consultation with third parties & 16 & 14.4 & 2 & 5.1 \\
\hline & Sub-total & 55 & 49.5 & 8 & 20.5 \\
\hline & Grand total & 163 & - & 45 & - \\
\hline
\end{tabular}

N.B. $45 \%$ of 244 AEP questionnaire respondents and $25 \%$ of $153 \mathrm{FD}$ respondents made individual comments. The total number of comments recorded is greater than the sum of respondents who made comments as some commented on more than one issue.

'It has to be said that the client's business is relatively straightforward and no contentious issues have arisen' (AEP).

The highest number of FD comments fall into sub-category 1.2 (co-operative and interactive relationship). Respondents emphasise the constructive and professionally co-operative nature of the relationship:

'It is the responsibility of the directors to prepare accounts which give a true and fair view. Discussions are held with the auditors to ensure that the true and fair view is provided. It follows that the process of finalising the form and content of accounts is more in the nature of a co-operative effort to interpret and apply complex accounting standards to real situations, rather than the process of positional bargaining' (FD).

'We have very few areas of serious disagreement with our auditors - good come and go on both sides' (FD).

'I consider we have a particularly constructive relationship with our auditors and in the last two years with which I have been involved there have been no serious differences of view between the group and our auditors' (FD).

'Most issues which have been discussed arise as a result of the interpretation of the requirements and their application in practice. The discussions are in my view best described as "collaborations"' (AEP).

'Generally both sides are well prepared and professional in their discussions which normally leads to satisfactory outcomes' (AEP).

'Negotiation is rarely necessary. The client respects and accepts the advice given following discussion - a consequence of a long and successful relationship' (AEP).

Respondents commenting under sub-category 1.3 (problems discussed and resolved at an early stage) indicate how conflict can be avoided by identifying and resolving potentially contentious issues before they become time critical. Different views are expressed by FDs about the role of the auditor in bringing issues forward. AEPs perceive early discussions as extremely important and to some extent dependent on a good relationship with their client: 
'All discussions take place at group level as early as possible to avoid entering the negotiation stage' (FD).

'It is our policy to discuss matters as openly and as early as possible. We generally know the subjective areas and put these to the auditors for discussion. I cannot remember when the auditors last initiated discussion in an area of principle although they do raise issues specifically arising from the year-end audit of divisions' (FD).

'There is good ongoing discussion with our auditors who are good at being pro-active on accounting issues. This eliminates the need for any negotiation over the year end figures since all discussions during the course of the year result in agreement in principle' (FD).

'Client FD is more amenable to accepting change if given adequate notice so colleagues/city analysts can be advised' (AEP).

'Early identification and discussion of potential areas of disagreement is critically important. This enables views to be reconciled before any entrenched positions are taken up. In turn the 'no surprises' approach relies on an open relationship between audit partner and $F D^{\prime}(A E P)$.

'The audit is a continuous process and in a good auditor/client relationship issues will be discussed in principle well before numbers are discussed/established. Therefore that numbers have not been changed as a result of discussions with client $X$ indicates, in my humble opinion, a good relationship (not a compliant auditor!)' (AEP).

'Generally if issues are identified at an early stage discussion process does not lead to negotiation and compromise' (AEP).

Responses in category two (attitudes to the regulatory framework) are varied and few FDs commented. Sub-category 2.1 (company attitude to compliance) includes some trenchant comments from the FDs who did respond indicating a belief that they are definitely in control, and insights from the AEPs about the differences in competence and attitudes among their clients and the problems and tensions which arise from companies meeting market expectations:

'If the auditors believe an approach is wrong or inappropriate we will discuss it, but if there is a difference of view which cannot be reconciled the company view prevails - unless it is a qualifying matter, in which case the company has a more difficult decision to take' (FD).
'Accounts prepared by the company - signed by the auditor' (FD).

'Client is a blue chip company anxious to maintain reputations for clear and proper financial reporting' (AEP).

'The FD has very high integrity and thus the resolution of issues is more straight forward than on some of my other clients' (AEP).

'This client needs accounting guidance and will usually change accounting treatment if negotiated tactfully. They do not appreciate how poor their internal accounting is' (AEP).

'The main factor is the balancing of our requirements to show a true and fair view with the pressures on the company to publish an "acceptable" result i.e. commercial considerations of market expectations, shareholders, trends etc' (AEP).

In sub-category 2.2 two of the three FDs are critical of the regulatory framework. The AEPs cite some specific accounting standards, problems of materiality and the need to deal with changes to the framework. There are differing views from the AEPs on the changing framework:

'Financial reporting standards are becoming too detailed and onerous' (FD)

'Judgment re what constitutes 'material' in any set of accounts' (AEP).

'A number of companies appear to have different interpretations of accounting standards...It is often difficult for us to answer the client' (AEP).

'Clear accounting standards - clear decisions' (AEP).

'Most discussion focuses on new reporting requirements and how they are to be interpreted in this context' (AEP).

Category three brings together situations where respondents have referred to the influence and involvement of other parties on the outcomes of interactions and where negotiations are directly referred to. Interestingly, there are few comments from FDs in this category. In sub-category 3.1 (comments on more difficult interactions) where FDs made six comments in all, four refer to audit fees as being the main area of contention. The AEPs make no reference to fees at all. One FD expresses his expectation that auditors would stand their ground on everything but fees. The AEPs generally expressed the view that if they stand up for themselves they are respected but there is a need to present a 
good case. The threat of qualification and the Financial Reporting Review Panel is referred to: 'I would hope that the auditors have a professional threshold beyond which they would not go. With the exception of fee levels, I do not believe that we have put them in a position where such a boundary is crossed - nor would I expect us to do $s o^{\prime}(F D)$.

'The only items are fees and the unacceptable size of them' (FD).

'We dug our heels in and they had to comply' (AEP).

'It was made quite clear we would not sign before the information improved' (FD).

'Auditor must stand his ground on important issues. Possibility of qualification is not seriously acceptable to client... Reference to going concern scenario is downside scenario used to nudge client to go that step further and protects us' (AEP).

'Threat of Review Panel' (AEP).

'Provided we feel strongly enough about an issue, the client will always accept the alteration to the number or the disclosure, but we must be able to explain our position robustly at all times' (AEP).

In sub-category 3.2 the AEPs refer to the involvement of other directors, mainly the audit committee in the negotiation process. With one exception the audit committee was seen as supportive of the auditors. The FDs made no reference at all either to non-executive directors or to audit committees:

'Are non-executive directors really going to support auditors opinions in many cases in practice? I believe that in most cases the NEDs will side with executive management and so only in a very few cases would the audit committee support the external auditors' views' (AEP).

'The audit committee is strong, independent and comprised of experienced senior industrialists. This has made the auditors life easier as the executive directors realise that the audit committee would back up the auditors if overly aggressive/adventurous policies/disclosures were put forward' (AEP).

'The role of the audit committee has without doubt been extremely helpful and they have on several occasions supported us and not their own finance director' $(A E P)$.

'Audit Committee fully briefed; never placed in the position of having to arbitrate between company and auditors - the arguments are given to the committee, with an explanation of why (proposed) course of action/treatment has been adopted. Full access to AC by auditors; strong chairman of AC (Finance director of a large plc) (AEP).

A further influence on the outcome of negotiations, the seeking of advice from third parties, is in sub-category 3.3. Only two FDs commented in this category and both criticised the activities of auditors' in-house technical departments. The AEPs took a different view, finding the in-house consultation procedures, whether from technical departments or other partners, constructive and supportive in carrying their points:

'Discussions are normally timely, organised and amicable, but influence of London technical departments particularly late in the audit have not been well received. More recently decision making of auditors has been decentralised which has improved this situation' (FD).

'The negotiations that took place were more between the audit team and their technical department, i.e. the reconciliation between theory (technical dept) and practice (audit team). We were bemused (and irritated) bystanders' (FD).

'Internal consultation involving senior partners totally independent of client engagement provides considerable support/weight to auditors' viewpoint. As well as helps to ensure all alternatives and implications are assessed' (AEP).

'As a matter of course issues on a listed company which require significant negotiation are referred to a second partner/technical department and the client is aware of this. The external source referred to above was the client's solicitors concerning a matter of contingent liability/litigation the client was facing' (AEP).

'Many discussions have taken place but all in a professional and friendly manner. Advice taken from our firm's technical department on a whole range of issues but only to confirm our own views, i.e. as a check in the normal course of our work' (AEP).

'We were able to concur with client X's proposals in each case after discussion and internal second opinion (which was always the same as the first opinion)' (AEP).

'Full and frank discussion, including initial disagreement, discussion with independent "second" partner and technical partner. Persuaded client to accept our approach' (AEP).

This analysis indicates the importance of a good working relationship and mutual respect between the auditor and the finance director and the continuing nature of the audit process. A key 
mechanism for avoiding conflict is perceived to be identification and resolution of potential problems at an early stage before time pressures make them critical. The company's own attitude to compliance is also fundamental to the relationship. A good attitude to compliance leads both parties to co-operate to find the right solution, but resolution of problems is also subject to the tensions of market expectations for company performance.

There are mixed views about the complexity of the current regulatory framework and varying degrees of reliance by companies on their auditors for advice in complying with it, particularly with new pronouncements.

Where negotiation takes place and interactions are more difficult the AEPs rely heavily on consultation within their firms, whereas the FDs who commented found the technical departments' late interventions an irritation. Audit committees are mainly, but not always, viewed by AEPs as an additional support in negotiations. The importance for AEPs of standing up for themselves on key issues is emphasised and reference is also made to the fall-back positions of the threat of a referral to the Financial Reporting Review Panel (FRRP) and a qualified audit report. Interestingly, the FDs make no reference at all to audit committees and little reference to difficult interactions other than fee negotiations whereas the AEPs make no reference to fees at all.

\section{CONCLUSIONS}

This paper goes behind the publicly observable financial statements and audit report to uncover the issues relating to the attest service debated at the primary interface between auditors and their auditees. To date, there are no published studies that provide direct evidence on this topic that is drawn from real-life settings. Our focus is on the audit process, in contrast to previous published empirical studies in this area that focus on publicly observable outcomes. Our findings contribute to our understanding of the nature of the audit service, in particular the value added by auditors, measured in terms of the advice and support given and the impact upon the financial statements.

Two general findings arise from the evidence presented in this paper. First, the general picture of the audit process to emerge, from the combi- nation of the quantitative data and the individual comments, is of the audit process being a continuing co-operative and consensual process, where problems are identified and addressed as they arise. The process benefits from a good working relationship between the parties which is based on mutual understanding of each other's role. Commercial considerations are a key influence on company reporting strategy whereas for the auditor the primary influence is compliance with the regulatory framework. Thus, a balance has to be achieved. When faced with a difficult negotiation auditors strengthen their position by consulting within their firm. The importance of presenting a strong case is recognised. Audit committees are generally viewed as a valuable support mechanism from within the company. Auditors also support their case in extreme circumstances by threatening qualification and the possibility of a referral to the FRRP.

Second, the attest service includes a significant financial reporting and internal control-related advice component in addition to the activities strictly necessary to perform the attest function. This supports the findings of Beattie and Fearnley (1998a, p.20 and pp.24-25) who find that companies seek from their auditor guidance on accounting principles, comfort on internal controls and general business advice. Moreover, Beattie and Fearnley (1998b) report that where the auditor 'didn't give...sufficient or accurate advice' they were replaced (p.83). Thus, the mixing of audit and advice services is not a new phenomenon, contrary to the impression conveyed by recent contributions to the audit independence debate. What appears to have happened, however, is that, as a result of increasing competition and increasing business complexity, the expectations of directors as to what an audit can and should deliver have increased. Thus, audit firms' recent marketing initiatives have actively promoted the fact that other benefits arise from the attest function (i.e., the added-value audit). ${ }^{18}$ Some commentators view this as eliminating the very possibility of auditor independence. Yet auditors have always provided advice to clients. Nothing has, therefore, changed substantially - it is simply that the audit has been repackaged and an emphasis has been placed on the formal communication of existing knowledge already gathered during the course of the audit. There 
has been no radical change in audit, rather, a process of gradual change has occurred. The concern expressed about the added-value audit seems to create a paradox: as the regulatory framework changes and becomes more complex (in an effort to improve the quality of financial reporting), clients will increasingly rely on advice from their auditors; at the same time, the very provision of this advice is claimed by some to preclude auditor independence, which is itself a key requirement for audit quality and, hence, quality financial reporting!

The use by commentators of the generic term 'advice' in this debate is perhaps unhelpful and misleading, leading to this apparent paradox. We believe that, to advance the debate about advice and independence, it is important to define explicitly the type of advice concerned. The attest function has never been stand-alone; some advice is integral to it. This includes compliance-related advice (i.e., accounting standards and Cadbury) and management letter advice on procedures. There may also be additional, informal general business advice not directly connected with the audit. These forms of advice, which are part of the added-value audit, must be distinguished clearly from pure consultancy engagements. Future research into the impact of auditor advice on auditor independence must address each type of advice separately.

This study has four main limitations. First, our research design would ideally have used matched samples, i.e., the FD and AEP from the same companies. This is, however, unlikely to be possible, due to auditor/company confidentiality considerations. Second, our analysis is based on declared responses, and incentives may exist for both under- and over-reporting of interaction and change to the financial statements. FDs may wish to understate the level of negotiation and change, whereas AEPs may wish to overstate it. The responses of each respondent type, however, provide some corroboration of the other. Third, we do not know the nature of the changes to the financial reports which have occurred due to auditor/auditee interaction. It may be that either the auditor's view has prevailed (the directors may or may not have come round to that view), or a compromise change may have been agreed through negotiation. Thus, our study does not permit conclusions to be drawn regarding the auditor's ability to withstand pressure from directors. Fourth, a postal questionnaire does not permit an analysis of the process of negotiation and conflict resolution. We intend to address the latter two limitations by conducting in-depth interviews with selected respondents who have experienced actual or potential conflict situations.

\section{ACKNOWLEDGEMENTS:}

The financial support of the Centre for Business Performance of the Institute of Chartered Accountants in England and Wales, and the support of the ICAEW's Audit Faculty and the Auditing Practices Board is gratefully acknowledged. We would also like to thank Roger Davis of PricewaterhouseCoopers and two anonymous reviewers for their helpful comments on earlier drafts of this paper.

\section{NOTES}

1. Other parties do sometimes become involved in top-level discussions (e.g., review partners and other main board members) but this is usually after the issue is discussed between the AEP and the FD, with these two individuals continuing to be involved in the discussions.

2. Any inefficiencies in their behavioural relationship, arising from conflict, could be costly to the auditor and/or the auditee (Wilcox and Smith, 1977, p.81).

3. A cooperative game theory model is explored by Hatherly et al. (1996).

4. This study uses audit fee data and data on the incidence of five earnings management techniques for 112 UK companies.

5. Conflict is also the subject of a recent experimental study in the accounting ethics literature, which finds that ethical reasoning moderated the relationship between locus of control (a personality variable) and the auditor's behaviour in an audit conflict situation (Tsui and Gul, 1996).

6. We are grateful to one of the anonymous reviewers for drawing this paper to our attention.

7. Their recent survey evidence shows that $84 \%$ of U.K. companies always receive a management letter after the final audit, with small companies being less likely to receive one. 
These are normally distributed to the board of directors or to the audit committee (if one exists), with reply via discussion (formal or informal), rather than by letter, being most common.

8. The 'other' issues most frequently specified were statements in the annual report concerning compliance with the Cadbury Code of Best Practice re internal controls and re going concern, directors' emoluments, segmental information, exceptional items, and audit partner rotation.

9. We also calculated the correlation using only the restricted subset of issues appearing in the top ten of either group $(n=14)$. The correlation is 0.306, which just fails to be significant at the $10 \%$ level (one-tailed).

10. We also calculated the correlation using only the restricted subset of issues appearing in the top ten of either group $(\mathrm{n}=11)$. The correlation is 0.406, which just fails to be significant at the $10 \%$ level (one-tailed).

11. Thirteen out of the 27 significant associations were also significant with respect to discussion (and in the same direction), the remaining 16 significant associations being with respect to negotiation only.

12. It is anomalous that in 15 cases ( $0.1 \%$ of total) change occurred without either discussion or negotiation.

13. These percentages exclude missing values.

14. The Cadbury Report states that audit committees have the potential to improve the quality of financial reporting by reviewing the financial statements on behalf of the board', 'strengthening the position of the external auditor, by providing a channel of communication and forum for issues of concern', and 'provide a framework within which the external auditor can assert his independence in the event of a dispute with management' (1992, appendix 4, para.4).

15. Kalbers and Fogarty (1993) provide an excellent critical review of extant studies on audit committee effectiveness. In an empirical study, they find the most significant power sources affecting effectiveness to be formal, written authority and observable support from top management (institutional factors) and the will to act (a personal factor). (See also Spiro, 1998.)
16. The comparable non-parametric test (Wilcoxon rank sums test) produced similar results.

17. New regulations require audit partner rotation at least every seven years.

18. There is some confusion over the term 'added-value audit'. Audit practitioners use it to mean audits that 'are performed in such a way that the findings can be interpreted and communicated to the client and form part of the business decision taking activity and add real value to the corporate entity' (personal communication with Gerry Acher, senior partner in KPMG UK, Chair of the ICAEW Audit Faculty and formerly chair of KPMG's world wide auditing committee). Some commentators have, however, taken the term to mean consultancy-related services.

\section{REFERENCES}

AICPA (1990). AICPA Codification of Statements of Auditing Standards. Commerce Clearing House.

APB (1992). The Future Development of Auditing: A Paper to Promote Public Debate. (The MacFarlane Report). London: Auditing Practices Board.

APB (1994). The Audit Agenda. London: Auditing Practices Board.

Agacer, G.M. and Doupnik, T.S. (1991). Perceptions of auditor independence: a cross-cultural study. International Journal of Accounting, 26, pp. 220-237.

Antle, R. and Nalebuff, B. (1991). Conservatism and auditor-client negotiations. Journal of Accounting Research, 29, Supplement, pp.31-59.

Bartlett, R.W. (1993). A scale of perceived independence: new evidence on an old concept. Accounting, Auditing and Accountability Journal, 6(2), pp.52-67.

Beattie, V., Brandt, R. and Fearnley, S. (1999). Perceptions of auditor independence: U.K. evidence. Journal of International Accounting Auditing and Taxation, 8(2), pp.67-107.

Beattie, V. and Fearnley, S. (1995). The importance of audit firm characteristics and the drivers of auditor change in UK listed companies. Accounting and Business Research, 25, pp.227-239.

Beattie, V. and Fearnley, S. (1998a). What Companies Want (and Don't Want) From Their Auditors. London: Institute of Chartered Accountants in England and Wales.

Beattie, V. and Fearnley, S. (1998b). Auditor changes and tendering: UK interview evidence. Accounting, Auditing $\mathcal{E}$ Accountability Journal, 11(1), pp.72-98.

Brass, D.J. and Burkhardt, M.E. (1993). Potential power and power use: An investigation of structure and behaviour. Academy of Management Journal, 36(3), pp.441-470. 
Cadbury Report (1992). Report of the Committee on the Financial Aspects of Corporate Governance. London: Gee and Co.

Chambers, A. and Penman, S. (1984). Timeliness of reporting and the stock price reaction to earnings announcements. Journal of Accounting Research, 22, pp.21-47.

Dye, R.A. (1991). Informationally motivated auditor replacement. Journal of Accounting and Economics, 14, pp.347-374.

Fellingham, J.C. and Newman, D.P. (1985). Strategic considerations in auditing. The Accounting Review, October, pp.634-650.

Firth, M. (1980). Perceptions of auditor independence and official ethical guidelines. The Accounting Review, July, pp.451-466.

Fisher, J, Schatzberg, J.W. and Shapiro, B.P. (1996). A theoretical and experimental examination of strategic auditor-client interaction. Advances in Accounting, 14, pp.135-160.

Gibbins, M., Salterio, S. and Webb, A. (1999). Evidence about auditor-client management negotiation concerning client's financial reporting. Working Paper.

Gray, R.H. with Bebbington, J. and Walters, D. (1993). Accounting for the Environment. London: Paul Chapman Publishing Ltd.

Griffiths, I. (1996). New Creative Accounting. Macmillan.

Gul, F.A. (1991). Size of audit fees and perceptions of auditors' ability to resist management pressure in audit conflict situations. Abacus, 27(2), pp.162-172.

Gulliver, P.H. (1979). Disputes and Negotiations: A Cross-Cultural Perspective. New York: Academic Press.

Hansen, S.C. and Watts, J.S. (1997). Two models of the auditor-client interaction: tests with United Kingdom data. Contemporary Accounting Research, 14(2), Summer, pp.23-50.

Hatherly, D., Nadeau, L. and Thomas, L. (1996). Game theory and the auditor's penalty regime. Journal of Business Finance and Accounting, 23(1), January, pp.29-45.

Hill, J. and Ingram, R.W. (1989). Selection of GAAP or RAP in the savings and loan industry. The Accounting Review, 4, pp.667-679.

ICAS (1996). Integrity, Objectivity and Independence. Statement of Professional Conduct No. 1. Edinburgh: Institute of Chartered Accountants of Scotland.

Kalbers, L.P. and Fogarty, T.J. (1993). Audit committee effectiveness: an empirical investigation on the contribution of power. Auditing: A Journal of Practice and Theory, 12(1), Spring, pp.24-49.

Kennedy, G., Benson, J. and McMillan, J. (1984). Managing Negotiations, 2nd ed. London: Business Books.

Kinney, W.R. (1975a). A decision theory approach to the sampling problem in auditing. Journal of Accounting Research, Spring, pp.117-132.
Kinney, W.R. (1975b). Decision theory aspects of internal control system design/compliance and substantive tests. Journal of Accounting Research, Supplement, pp.14-29.

Knapp, M.C. (1985). Audit conflict: an empirical study of the perceived ability of auditors to resist management pressure. The Accounting Review, 60(2), pp.202-211.

Knapp, M.C. (1987). An empirical study of audit committee support for auditors involved in technical disputes with client management. The Accounting Review, 62(3), pp.578-588.

Kramer, R.M. and Messick, D.M., (eds.) (1995). Negotiation as a Social Process. CA:Sage Publications.

Kross, W. and Schroeder, D. (1984). An empirical investigation of the effect of quarterly earnings announcement timing on stock returns. Journal of Accounting Research, 22, pp.153-176.

Levitt, A. (1998). The Numbers Game. Address delivered at the NYU Center for Law and Business, 28 September.

Lindsay, D. (1992). Auditor-client conflict resolution: an investigation of the perceptions of the financial community in Australia and Canada. International Journal of Accounting, 27, pp.342-365.

Lord, A.T. (1992). Pressure: a methodological consideration for behavioural research in auditing. Auditing: A Journal of Practice and Theory, 11(2), Fall, pp.89-108.

Manson, S., McCartney, S. and Sherer, M. (1994). The Usefulness of Management Letters, Certified Research Report 38. London: Chartered Association of Certified Accountants.

Mastenbroek, W. (1989). Negotiate. Oxford: Basil Blackwell.

Metcalf Committee (1976). The Accounting Establishment: A Staff Study. U.S. Senate, Subcommittee on Reports, Accounting and Management of the Committee on Government Operations. Washington, DC: Government Printing Office.

Nicotera, A.M. (1993). Beyond two dimensions: a grounded theory model of conflict-handling behavior. Management Communication Quarterly, 6(3), pp.282-306.

NYSE/NASD (1999). Report and Recommendations of the Blue Ribbon Committee on Improving Audit Committee Effectiveness. New York Stock Exchange and National Association of Securities Dealers, New York.

Oppenheim, A.N. (1966). Questionnaire Design and Attitude Measurement. Heinemann.

Pong, C.K.M. and Whittington, G. (1994). The determinants of audit fees: some empirical models. Journal of Business Finance and Accounting, 21(8), pp.1071-1095.

POB (1986). Public Perceptions of Management Advisory Services Performed by CPA Firms for Audit Clients, SEC Practice Section, AICPA. New York: Public Oversight Board. 
Scheutze, W.P. (1994). A mountain or a molehill? Accounting Horizons, 8(1), pp.69-75.

Schleifer, L.L.F. and Shockley, R.A. (1990). Policies to promote auditor independence: more evidence on the perception gap. Journal of Applied Business Research, 7(2), pp.10-17.

Siegel, S. and Castellan, N.J. (1988). Non-parametric Statistics for the Behavioural Sciences. McGraw-Hill.

Spiro, L.F. (1998). An evolutionary perspective on audit committee effectiveness. Corporate Governance: An International Review, 6(1), pp.29-38.

Teoh, H.Y. and Lim, C.C. (1996). An empirical study of the effects of audit committees, disclosure of nonaudit fees, and other issues on auditor independence: Malaysian evidence. Journal of Accounting, Auditing and Taxation, 5(2), pp.231-248.

Treadway Committee (1987). Report of the National Commission on Fraudulent Financial Reporting. National Commission on Fraudulent Financial Reporting.

Trompeter, G. (1994). The effect of partner compensation schemes and generally accepted accounting principles on audit partner judgement. Auditing: A Journal of Practice and Theory, 13(2), Fall, pp.56-68.

Tsui, J.S.L. and Gul, F.A. (1996). Auditors' behaviour in an audit conflict situation: a research note on the role of locus of control and ethical reasoning. Accounting, Organizations and Society, 21(1), January, pp.41-51.

Tweedie, D. and Whittington, G. (1990). Financial reporting: current problems and their implications for systematic reform. Accounting and Business Research, 21, pp.87-102.

Wallace, R.S.O. and Mellor, C.J. (1988). Non-response bias in mail accounting surveys: a pedagogical note. British Accounting Review, August, pp.131-139.
Wilcox, K.A. and Smith, C.H. (1977). Role discrepancies and the auditor-client relationship. Accounting, Organizations and Society, 2(1), pp.81-97.

\section{AUTHOR PROFILES:}

Vivien Beattie MA(Hons), CA PhD is Professor of Accounting in the Department of Accounting, Finance and Law, University of Stirling. She currently holds the part-time appointment of Director of Research of The Institute of Chartered Accountants of Scotland and is a member of the ASB's Academic Panel. Her main research interests are external audit and business reporting.

Stella Fearnley is a Reader in Accounting in the Department of Accounting and Management Science, University of Portsmouth and a former senior technical manager in Grant Thornton. She is an elected member of the Council of The Institute of Chartered Accountants in England and Wales and currently Deputy Chair of its Centre for Business Performance.

Richard Brandt is a Research Fellow in the Department of Accounting and Management Science, University of Portsmouth. He was for nine years Head of Audit at Grant Thornton, and is a former member of the UITF. He is editor of the 1999-00 edition of 'Auditing and Reporting', published by the ICAEW. 